Amr Hosny ${ }^{1}$

\title{
Political Stability, Firm Characteristics and Performance: Evidence from 6,083 Private Firms in the Middle East
}

\author{
${ }^{1}$ IMF, Washington, DC, USA, E-mail: ahosny@imf.org
}

\begin{abstract}
:
Using firm-level data from an EBRD/EIB/WB joint survey covering more than 6,000 private firms in eight countries in the Middle East and North Africa, this paper (i) examines the relationship between firm characteristics and their perception of the effect of political instability on their operations and (ii) tests whether political instability has had a negative effect on firm performance. Using ordered and binary probit/logit models, we find that (i) export-oriented and larger-sized firms are more likely to report political instability as a sever obstacle to their operations. Using OLS and an endogenous treatment linear regression models, we find that (ii) the perception of political instability is negatively associated with firm performance, and after correcting for endogeneity it can even have a negative causal effect on firms' sales and employment growth, all else held constant. Results are largely robust to different specifications and econometric methods.
\end{abstract}

Keywords: political stability, treatment effects, Middle East, World Bank Enterprise Surveys

JEL classification: L25

DOI: 10.1515/rmeef-2017-0005

\section{Introduction}

By now, it is well understood that the development of a vibrant and dynamic private sector is essential for growth and job creation in the Middle East and North Africa (MENA) region. Public sector investments and jobs cannot be solely relied on to boost growth and generate much-needed jobs, especially for young populations of the region. Public authorities can, however, play an equally crucial role by creating a business environment conducive to private sector development. This would require a clear understanding of current business practices and private firms' characteristics and performance.

In 2013-2014, a joint EBRD/EIB/WB initiative conducted the MENA Enterprise Surveys (MENA ES) to assess the environment for private enterprise and business development in eight countries in the region (Table 1). ${ }^{1}$ Countries covered by the survey are: Djibouti, Egypt, Jordan, Lebanon, Morocco, Tunisia, the West Bank and Gaza and Yemen. Over 6,000 private firms in the manufacturing and services sectors are asked questions about their performance and the business environment in which they operate. A joint report by the European Bank for Reconstruction and Development (EBRD), the European Investment Bank (EIB), and the World Bank Group (WBG) summarizes the results (see EBRD/EIB/WB 2016).

Table 1: MENA ES characteristics.

\begin{tabular}{ll}
\hline Countries covered & $\begin{array}{l}\text { Djibouti (266 firms), Egypt (2,897), Jordan (573), } \\
\text { Lebanon (561), Morocco (407), Tunisia (592), the West } \\
\text { Bank and Gaza (434), and Yemen (353). }\end{array}$ \\
\hline Sample & $\begin{array}{l}6,083 \text { official private firms, which are: } \\
\text {-Registered, }\end{array}$ \\
& $\begin{array}{l}\text { - Have at least five full-time employees, and } \\
\text {-In the manufacturing or services sectors }\end{array}$ \\
Sampling method & $\begin{array}{l}\text { Stratified random sampling, stratified by: } \\
\text {-Regional location within each country, }\end{array}$ \\
& -Firm size, and \\
& -Sector of activity \\
\hline
\end{tabular}

Amr Hosny is the corresponding author.

(C) 2017 Walter de Gruyter $\mathrm{GmbH}$, Berlin/Boston. 
Source: EBRD/EIB/WB (2016)

Note: Further details on the breakdown of individual firms by sector of activity and location are available in EBRD/EIB/WB (2015). Firm size is defined as small (5-19 employees), medium (20-99 employees), and large (more than 100 employees). For more details, see EBRD/ElB/WB (2015), including on weights, eligibility, and advantages of stratified over simple random sampling.

Understanding they key constraints to business is vital to allow the private sector to become an engine of growth. As explained by EBRD/EIB/WB (2016), the MENA ES includes data on the experiences of private firms with a broad range of dimensions of the business environment in which they operate, including political instability, access to finance, corruption, infrastructure, crime, and competition, among others. The MENA ES also provide information on individual firm characteristics and the cost of labor and other inputs; workforce composition, participation of women, trade, innovation and technology, and management practices.

Political instability has been identified as the number one constraint to business by many firms. In the MENA ES, firms were asked to what degree are different dimensions mentioned above an obstacle to their current operations. An important finding of the survey was that firms identified political instability, among a menu of other business obstacles, as the most severe obstacle to their operations in many countries of the region. More generally, survey results indicated that four main particular constraints stand out as identified by private firms. These are: political instability, corruption, unreliable electricity supply and inadequate access to finance.

In this context, the objective of this paper is twofold. First, to examine the relationship between firm characteristics and their perception of the effect of political instability on their operations. Second, to test whether political instability has had a negative causal effect on firm performance.

On the first objective, we find that domestic-oriented and smaller-sized firms are more likely to report political instability as a sever obstacle to their operations. Empirical results indicated that these firms are more likely to report political instability as a severer obstacle, as compared to export-oriented and larger-sized firms. This result holds under different econometric estimation techniques (ordered probit/logit vs binary probit/logit), as well as other robustness checks such as changing model specifications and inclusion of country fixed dummies.

On the second objective of this study, results suggest that political instability has had a negative and statistically significant effect on firm performance in MENA. We start by using simple OLS regressions. Empirical results suggest that perception of political instability is associated with lower firm performance, all else held constant. We then use treatment effect models to obtain a causal interpretation of the results. Using an endogenous treatment-regression model that allows the estimation of a linear regression which includes an endogenous binary treatment variable, we confirm our earlier findings and report a negative and statistically significant causal effect. Results hold against alternative specifications and whether we include country fixed dummies or no.

To the best of our knowledge, there exists no study that tests the causal effect of political instability on individual firm performance, especially in the case of the MENA region. Dethier, Hirn, and Straub (2010) provide a general survey of the recent literature examining the impact of the business climate on productivity and growth in developing countries using enterprise surveys. Kinda, Plane, and Véganzonès-Varoudakis (2015) use fixed effects regressions to study the correlation between the investment climate and firm technical efficiency in 22 MENA countries. They caution, however, that their results should be treated with caution, as they highlight covariates more than causal impacts. For instance, using survey results from the WBES from 98 countries, including 10 from the MENA region, Bhattacharya and Wolde (2012) use WBES data to test the significance of business constraints on firms in the context of a standard growth model and to show that inefficiencies in customs clearance are associated with underperformance in trade in MENA.

\section{An Initial Look at the Data}

The MENA ES is a representative sample of the formal private sector firms in the MENA region. Specifically, it covers 6,083 non-agricultural private sector firms across eight countries in the MENA region. To be included in the survey, firms needed to employ at least five employees and to operate in the manufacturing or services sectors. "Services" include retail, wholesale, hospitality, repairs, construction, information and communication technology and transport. ${ }^{2}$ Firms with 100 percent state ownership are excluded from this survey. As explained in EBRD/EIB/WB (2016), the survey design, sample frames and sampling weights ensure that the MENA ES are statistically representative of the private sector in each economy. 


\subsection{Survey Design}

\subsubsection{Political instability as the top obstacle}

Political instability is considered the top obstacle in almost half of the surveyed firms. Firms were asked What is the biggest obstacle affecting the operation of this establishment? ${ }^{3}$ Results reveal that, on average, around 47 percent of firms surveyed indicated that the biggest obstacle affecting their business is political instability (Figure 1). This is followed by access to finance (11 percent of firms), electricity (8 percent), corruption (7 percent), and informality (6 percent).

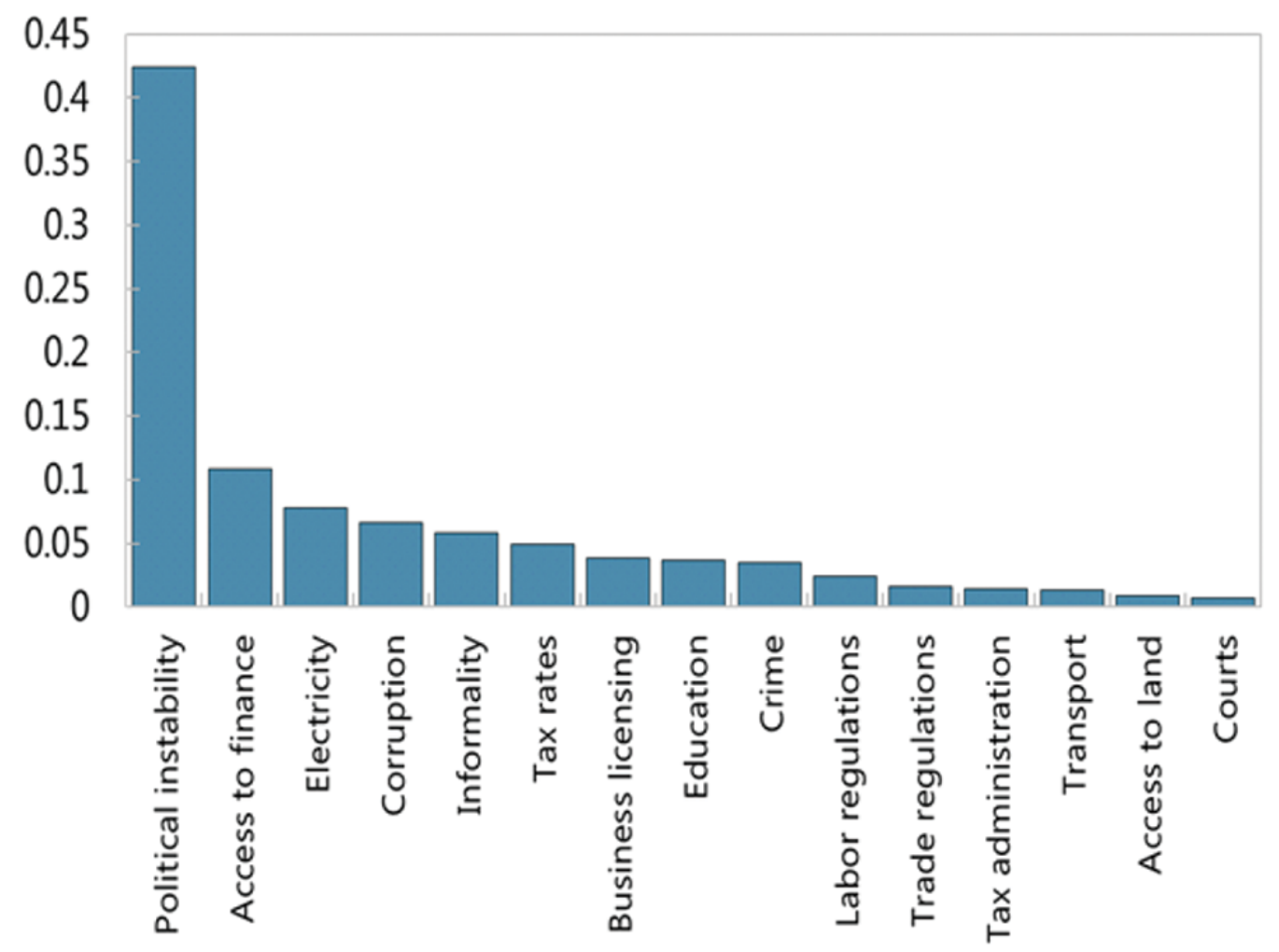

Figure 1: Top obstacles in the MENA ES countries (Percent of firms, overall average).

In Tunisia, Egypt, Lebanon and Yemen, political instability is considered the top obstacle in one out of two firms. Looking at the same question above at the country level, survey results indicate that political instability was chosen as the top obstacle in half the countries surveyed; namely: Tunisia, Egypt, Lebanon and Yemen. Moreover, one can see that almost one out of every two firms in these countries cite political instability as the top obstacle to their operations. For Djibouti, electricity seems to be the main obstacle to business in almost half the surveyed firms (46 percent). In Jordan and Morocco, access to finance has been chosen as the top business obstacle, although not by an overwhelming number of firms (Figure 2). 


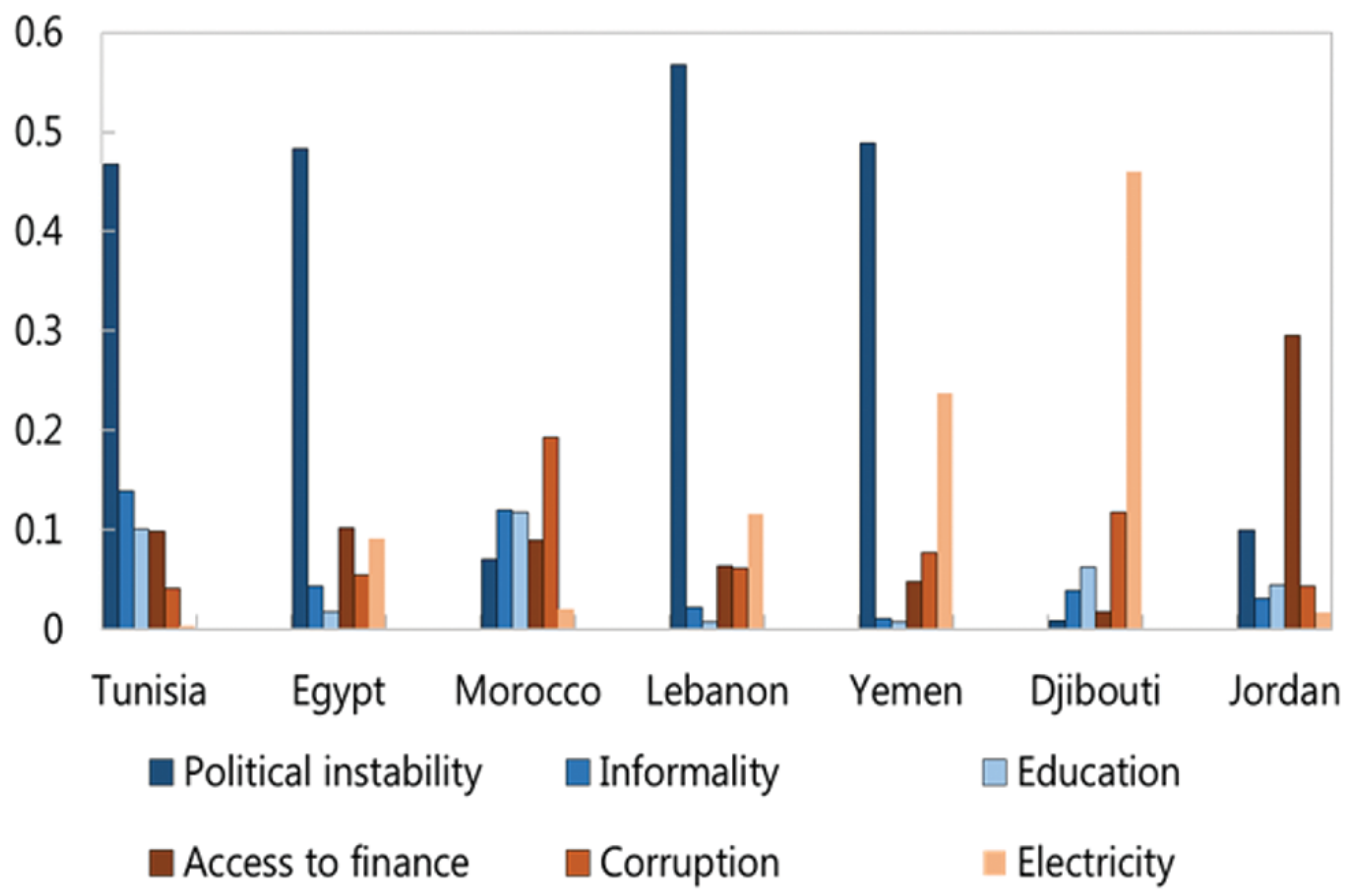

Figure 2: Top obstacles in the MENA ES countries (Percentage of firms, individual countries).

Most firms also cited political instability as a "very severe obstacle" to their operations. In addition to the above question on which dimension is the top obstacle, firms were also asked to evaluate each dimension separately (Figure 3). The question was: To what degree is political instability an obstacle to the current operations of this establishment? ${ }^{4}$ Firms were given choices ranging from no obstacle (0), minor obstacle (1), moderate obstacle (2), major obstacle (3), and very severe obstacle (4). The "very severe obstacle" response was chosen by most firms in Yemen (70 percent of firms), Lebanon (55 percent of firms), and Egypt (42 percent of firms). In Tunisia, it was cited as a "major obstacle" by most firms (34 percent of firms), followed by very severe obstacle ( 26 percent of firms). At the same time, most firms cited political instability as a "no obstacle" in Morocco (42 percent of firms), Jordan (11 percent), and Djibouti (2 percent). That said, although the perception of how political instability can affect firm's operations can very between individual MENA countries, the overall average for all countries suggests that political instability was cited as a very severe obstacle by 37 percent of firms, followed by major obstacle by 32 percent of firms. 


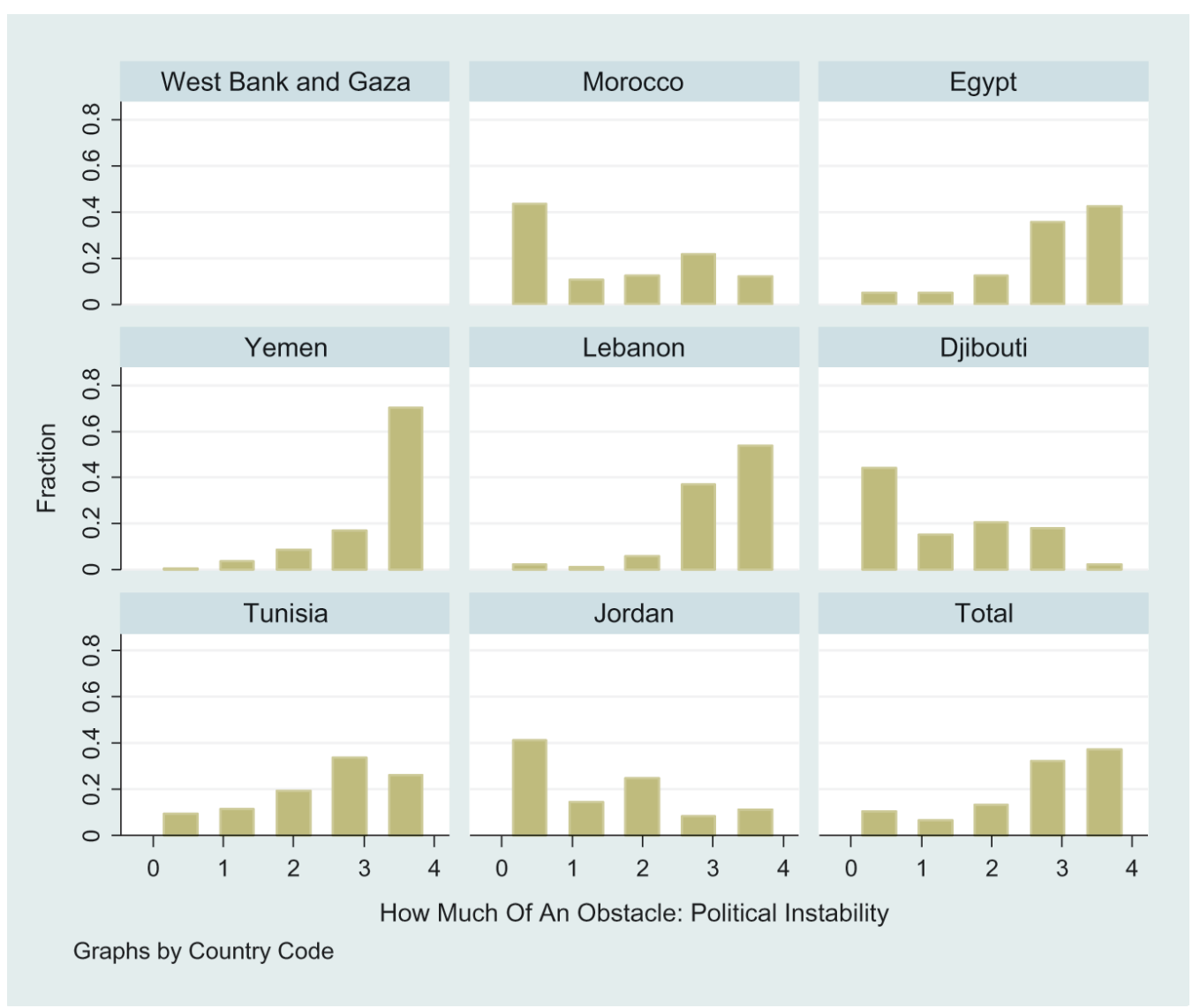

Figure 3: How much of an obstacle: political instability.

\subsubsection{Firm Characteristics}

On firm sales, most are directed toward the domestic market. Firms were asked What percentage of this establishment's sales were national sales? Indirect exports? Direct exports ${ }^{5}$ Most firm sales are directed toward the national market. This is especially the case in Egypt (95 percent of total sales), followed by Yemen (94), Morocco (89 percent), Djibouti (87 percent), Jordan (86 percent), Lebanon (86) and Tunisia (80 percent). This implies that Egypt's private firms are less open than all other countries covered by the survey, although the size of the domestic market in Egypt is much larger than all other countries. Tunisia and Lebanon can be considered the two more open countries covered by the survey, with the biggest share of direct exports as part of total sales, reaching and 16 percent in Tunisia and 12 percent in Lebanon. Focusing more on firms with direct exports representing 10 percent or more of total sales, we find that Egypt has the lowest average (7 percent), while Tunisia (30 percent) and Lebanon (32 percent) report the highest averages (Figure 4, Figure 5). 


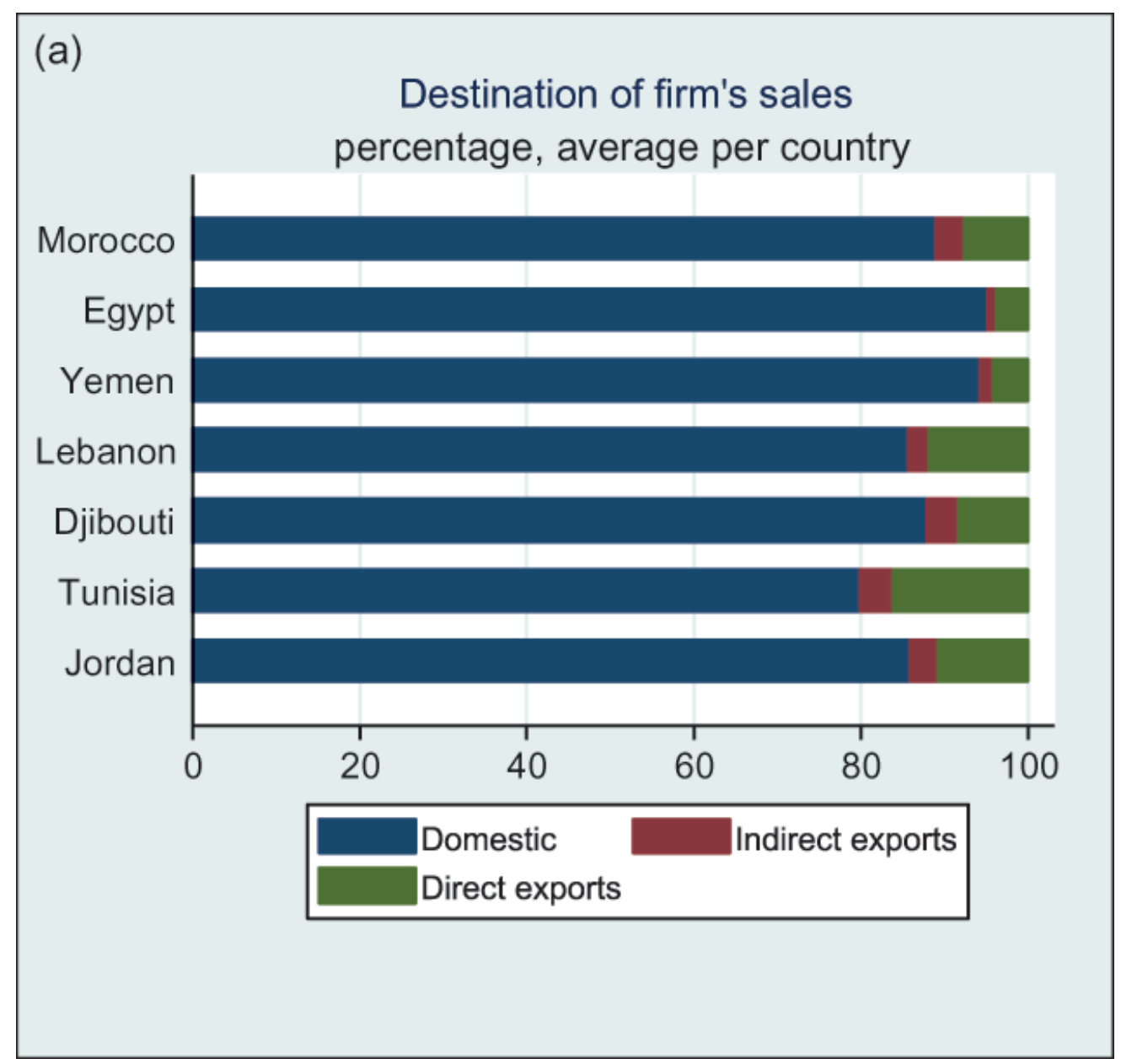

Figure 4: Destination of firm's sales.

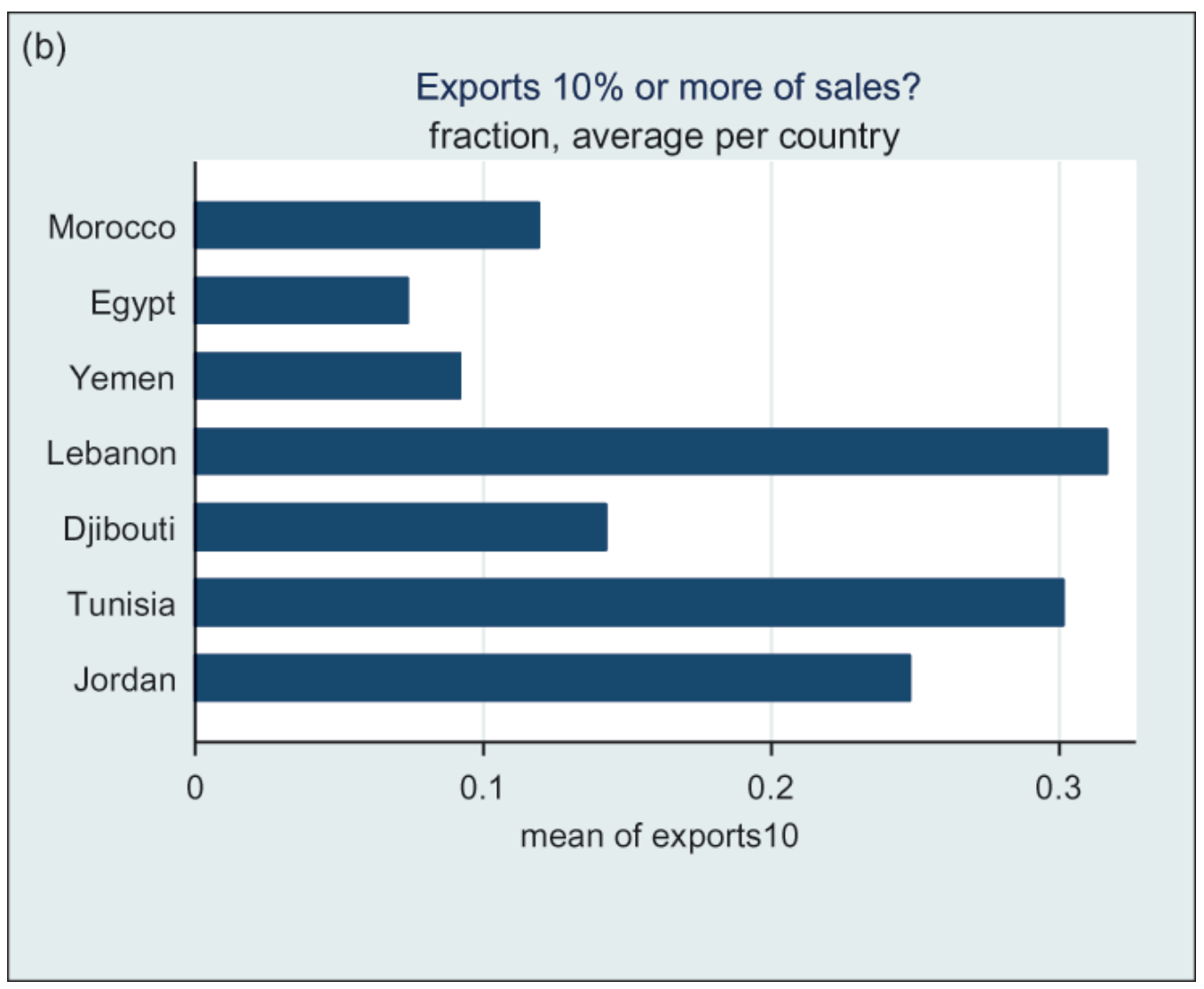


Figure 5: Exports $10 \%$ or more of sales?

On firm ownership, most are owned by private domestic individuals, companies or organizations. Firms were asked What percentage of this firm is owned by private domestic? Private foreign? Government/state? Other? ${ }^{6}$ Results indicate that most firms are domestically owned. These percentages are highest in Yemen (99 percent) and Lebanon (98 percent). Focusing on firms where foreign ownership is 50 percent or more, we find that Djibouti has the highest average (10 percent), followed by Morocco (7 percent) and Tunisia (6 percent) (Figure 6, Figure 7).

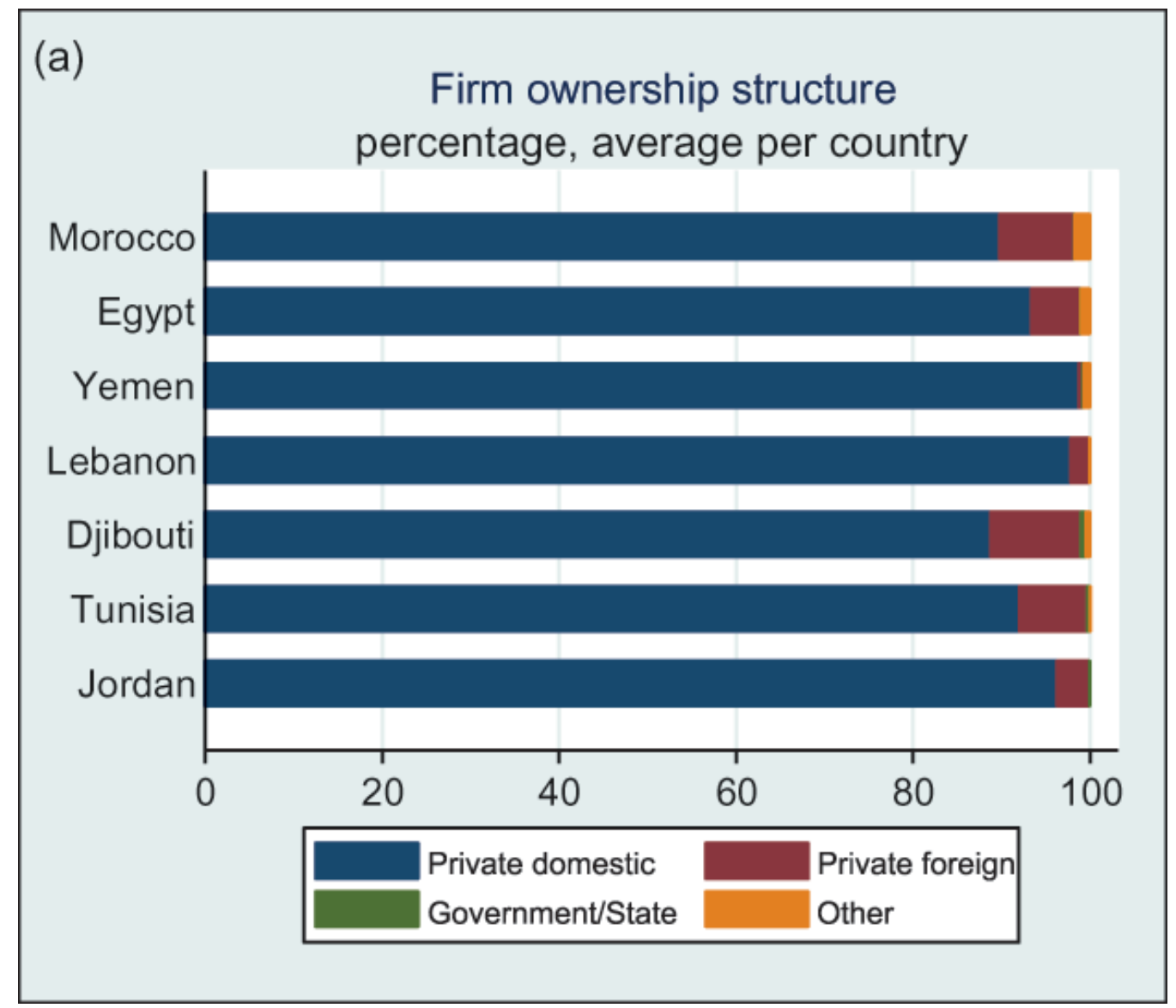

Figure 6: Firm ownership structure. 


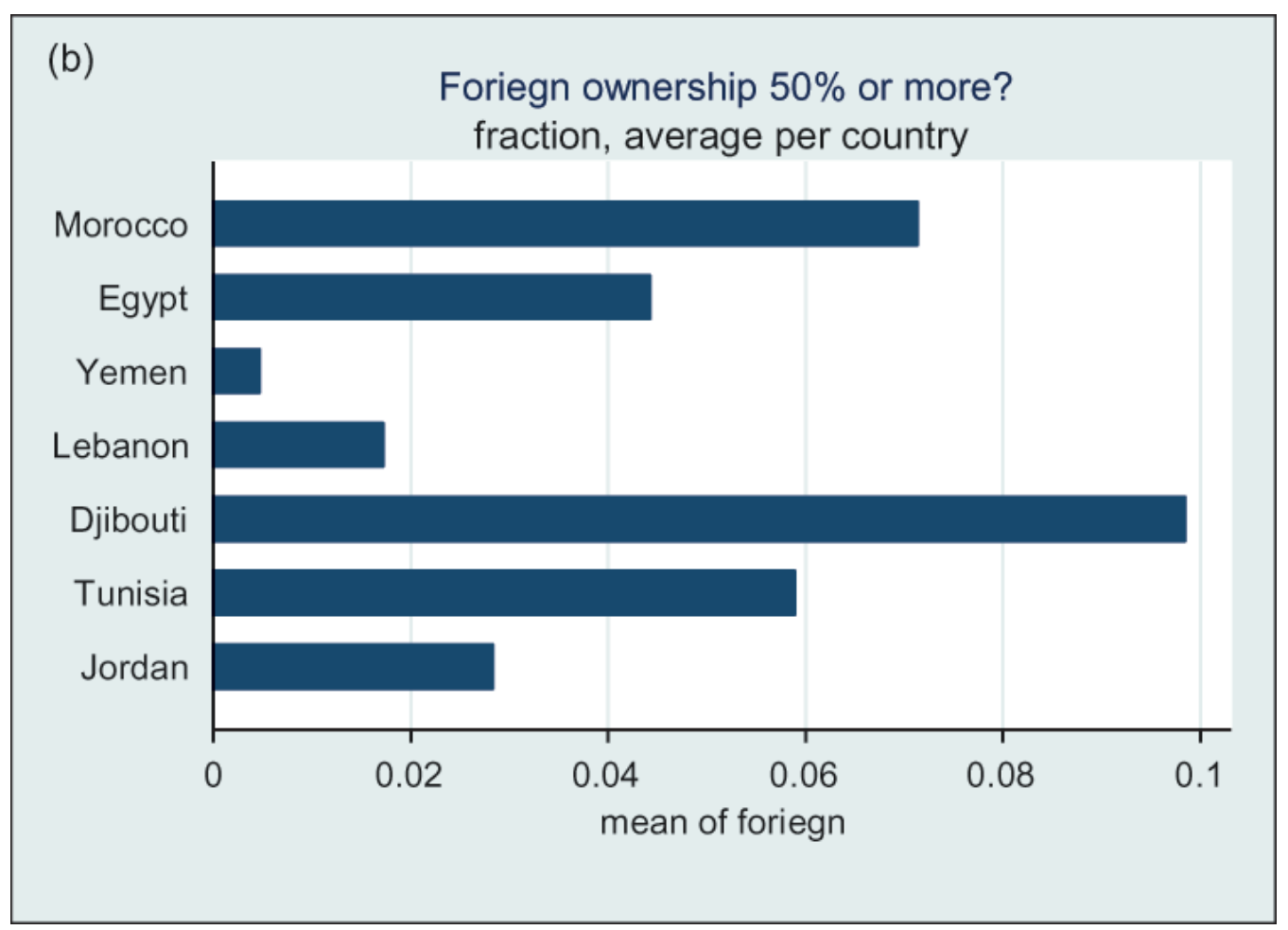

Figure 7: Firms' sampling size by country

On firm age, most firms surveyed on average report 15 years of operation or longer. Firms were asked: In what year did this establishment begin operations? ${ }^{7}$ On average, firms report an average life of 15 years (Egypt) or longer going to an average of 25 years (Yemen). Focusing on young firms, those having 5 years or less of operations, those were mostly located in Egypt (25 percent of firms), followed by Djibouti (22 percent) (Figure 8 , Figure 9).

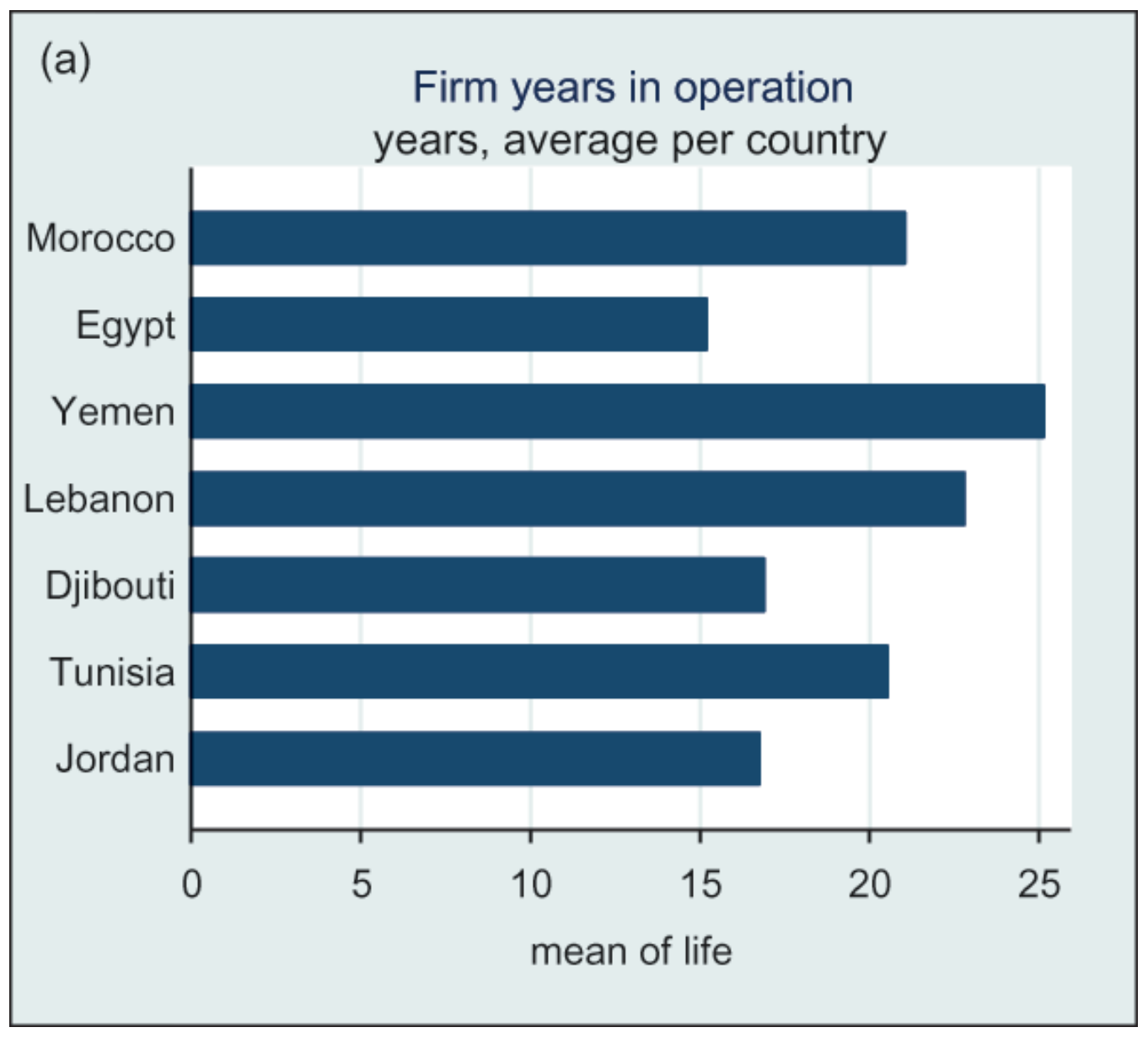


Figure 8: Firm years in operation

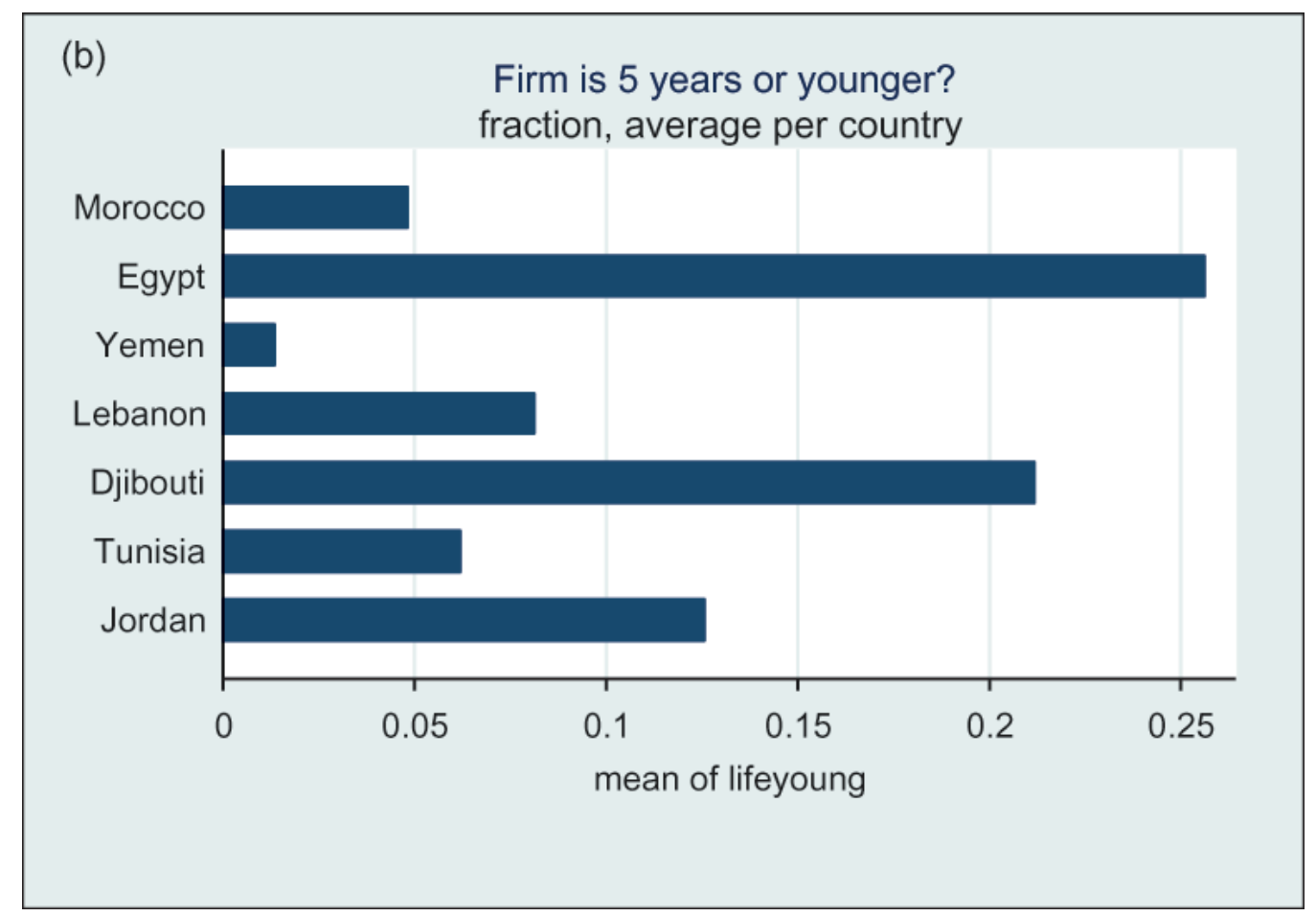

Figure 9: Firm is 5 years or younger?

On firm size, most firms interviewed were small firms. The question was: What is the firm's sampling size? ${ }^{8}$ Firms were given choices ranging from small (1 in Figure), medium (2), large (3), and small or medium (4). On average, small firms represented around 74 percent of surveyed firms, followed by medium (15 percent), small or medium (8 percent), and finally large (3 percent). In terms of individual countries, the largest share of small firms were Egypt and Yemen (89 percent) and the smallest Jordan (44 percent). Countries with the highest share of medium-sized firms were Morocco (36 percent) followed by Lebanon (33 percent). Countries with the highest share of large-sized firms were Jordan (24 percent) followed by Djibouti (7 percent) (Figure 10). 


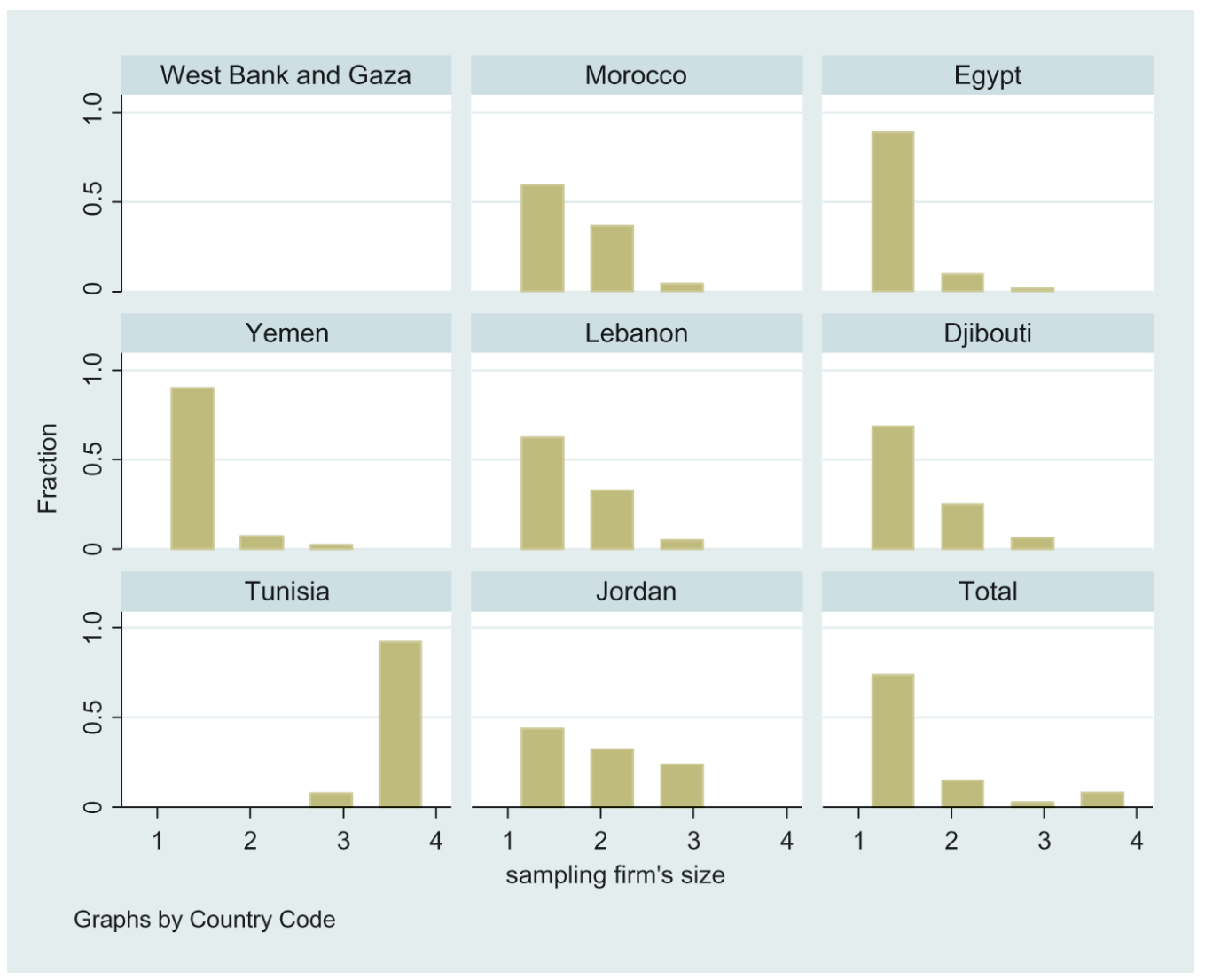

Figure 10: Firms' sampling size by Country.

\subsubsection{Firm Performance}

Firm performance varied across countries, with sales growth and employment growth ranging from negative to positive rates over the surveyed firms. This was in response to the following survey question on value of sales: What were the establishment's total annual sales last fiscal year (2012)? ${ }^{9}$ And 3 fiscal years ago (2009)? ${ }^{10}$ as well as the following question on number of employees: Number of permanent full time employees at end of last fiscal year (2012)? ${ }^{11}$ At end of 3 fiscal years ago (2009)? ${ }^{12}$ Firms in Yemen and Egypt, on average, witnessed negative growth rates in both sales ( -19 percent and -10 percent, respectively) and employment $(-10$ percent and -3 percent, respectively) over 2009-2012. Firms in Lebanon, on average, witnessed negative sales growth ( -4 percent), while those in Tunisia witnessed negative employment growth ( -0.5 percent). Positive firm performance was observed in remaining cases. Specifically, sales growth was positive in Djibouti (11 percent), Morocco (10 percent), Jordan (5 percent) and Tunisia (1 percent). Employment growth was positive in Djibouti (16 percent), Morocco (12 percent) and Jordan (10 percent) (Figure 11).

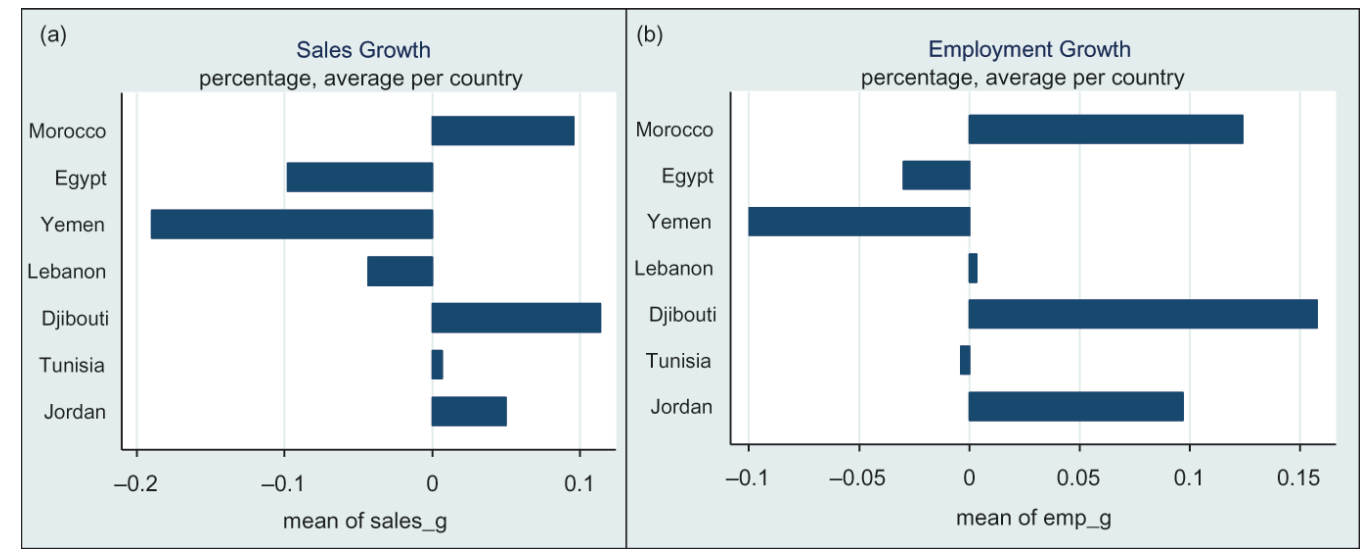

Figure 11: (a) Sales growth (b) Employment growth. 


\section{Empirical Methodology and Results}

\subsection{Political Instability and Firm Characteristics}

In this section, we estimate both an ordered and a binary logit/probit model to study the determinants of the severity of political instability as a business obstacle. Firms were asked: To what degree is political instability an obstacle to their current operations? Responses ranged from "No obstacle" (taking a value of 0 ) to "Very severe obstacle" (a value of 4 ).

\subsubsection{The Ordered Logit/Probit Evidence}

We use an ordered logit model to estimate the relationship between political instability, the major constraint to business in the MENA and firm characteristics. The dependent variable in the ordered logit is the ordinal responses to the above question, ${ }^{13}$ and independent variables are firm characteristics such as firm size, age, export status and type of ownership among others. Estimation of the ordered logistic model parameters for survey data is done by maximum pseudo-likelihood. We follow a specification similar to that of EBRD/EIB/WB (2016). Results are reported in Table 2.

Table 2: Ordered probit/logit.

\begin{tabular}{|c|c|c|c|c|}
\hline Variables & $\begin{array}{l}\text { (1) } \\
\text { Ordered probit }\end{array}$ & $\begin{array}{l}\text { (3) } \\
\text { Ordered probit }\end{array}$ & $\begin{array}{l}\text { (3) } \\
\text { Ordered logit }\end{array}$ & $\begin{array}{l}\text { (4) } \\
\text { Ordered logit }\end{array}$ \\
\hline Life of firm, in years & $\begin{array}{l}0.000372 \\
(0.00235)\end{array}$ & $\begin{array}{l}-0.000661 \\
(0.00240)\end{array}$ & $\begin{array}{l}0.000523 \\
(0.00403)\end{array}$ & $\begin{array}{l}-0.000569 \\
(0.00415)\end{array}$ \\
\hline Young firm $(\mathrm{Y} / \mathrm{N})$ & $\begin{array}{l}-0.196^{*} \\
(0.107)\end{array}$ & $\begin{array}{l}-0.00444 \\
(0.0996)\end{array}$ & $\begin{array}{l}-0.322^{*} \\
(0.179)\end{array}$ & $\begin{array}{l}-0.000420 \\
(0.167)\end{array}$ \\
\hline \multirow[t]{2}{*}{$\begin{array}{l}\text { Foreign ownership } \\
(\mathrm{Y} / \mathrm{N})\end{array}$} & 0.160 & 0.0364 & 0.252 & 0.0360 \\
\hline & $(0.122)$ & $(0.121)$ & $(0.214)$ & $(0.209)$ \\
\hline \multirow[t]{2}{*}{$\begin{array}{l}\text { Exports more than } \\
10 \% \text { of sales }(\mathrm{Y} / \mathrm{N})\end{array}$} & $-0.162^{*}$ & $-0.148^{*}$ & $-0.273^{*}$ & $-0.288^{*}$ \\
\hline & $(0.0945)$ & $(0.0880)$ & $(0.158)$ & $(0.152)$ \\
\hline Size & $\begin{array}{l}-0.115^{* *} \\
(0.0512)\end{array}$ & $\begin{array}{l}-0.135^{* * *} \\
(0.0242)\end{array}$ & $\begin{array}{l}-0.193^{* *} \\
(0.0908)\end{array}$ & $\begin{array}{l}-0.239^{*} \\
(0.0405)\end{array}$ \\
\hline \multirow[t]{2}{*}{$\begin{array}{l}\text { Firm part of larger } \\
\text { firm }(\mathrm{Y} / \mathrm{N})\end{array}$} & $0.170^{* *}$ & 0.114 & $0.306^{* *}$ & $0.235^{* *}$ \\
\hline & $(0.0755)$ & $(0.0694)$ & $(0.129)$ & $(0.114)$ \\
\hline \multirow[t]{2}{*}{$\begin{array}{l}\text { Manager experience, } \\
\text { in years }\end{array}$} & $0.00514^{*}$ & 0.00394 & $0.00909^{*}$ & $0.00831^{*}$ \\
\hline & $(0.00301)$ & $(0.00297)$ & $(0.00493)$ & $(0.00497)$ \\
\hline \multirow{2}{*}{$\begin{array}{l}\text { Manager education } \\
\text { level }\end{array}$} & -0.0378 & 0.00410 & -0.0670 & -0.00126 \\
\hline & $(0.0415)$ & $(0.0391)$ & $(0.0733)$ & $(0.0662)$ \\
\hline Observations & 5,111 & 5,111 & 5,111 & 5,111 \\
\hline Country FE & YES & $\mathrm{NO}$ & YES & $\mathrm{NO}$ \\
\hline
\end{tabular}

Note: Standard errors in parentheses. Estimation is done using survey weights. Constant and dummies not reported.

$* * * * 0.01, * * p<0.05, * p<0.1$

Domestic-oriented and smaller firms are more likely to report political instability as a severer obstacle. ${ }^{14}$ Coefficients attached to firms with exports representing 10 percent or more of sales and larger-sized firms are negative and statistically significant. These results hold whether we include country fixed effects or no. This implies domestic-oriented and larger firms are less likely to report political instability as a severer obstacle. Export-oriented firms, those where exports represent 10 percent or more of their total sales, are more focused on export markets and may therefore be less affected by internal political developments than domestic-oriented firms. Larger firms may also be better equipped to withstand disturbances from political instability, and therefore could perceive political instability as not so severe a constraint compared to smaller firms. On the other hand, estimations with country fixed effects (models 1 and 3 in Table 2) show that firms with experienced managers, older firms, and firms who are parts of a larger establishment are more likely to report political instability 
as a severer obstacle. Results, in general, are similar if we use the ordered logit or the ordered probit, and are robust to alternate specifications. ${ }^{15}$

\subsubsection{The Binary Logit/Probit Evidence}

As a robustness check, we re-do the above exercise using a binary probit/logit model. Specifically, we experiment with a probit/logit where we suppress the dependent variable into a simpler binary 0 or 1 indicator. The new dependent variable takes the value of 1 if responses are "major constraint" or "very severe constraint", while it takes a value of 0 if the response is "no obstacle", "minor obstacle" or "moderate obstacle". ${ }^{16}$ Results are reported in Table 3.

Table 3: Binary probit/logit.

\begin{tabular}{|c|c|c|c|c|}
\hline Variables & $\begin{array}{l}\text { (1) } \\
\text { Probit }\end{array}$ & $\begin{array}{l}(2) \\
\text { Probit }\end{array}$ & $\begin{array}{l}(3) \\
\text { Logit }\end{array}$ & $\begin{array}{l}(4) \\
\text { Logit }\end{array}$ \\
\hline Life of firm, in years & $\begin{array}{l}0.000668 \\
(0.00321)\end{array}$ & $\begin{array}{l}-0.000889 \\
(0.00298)\end{array}$ & $\begin{array}{l}0.000703 \\
(0.00549)\end{array}$ & $\begin{array}{l}-0.00168 \\
(0.00491)\end{array}$ \\
\hline Young firm $(\mathrm{Y} / \mathrm{N})$ & $\begin{array}{l}-0.218 \\
(0.137)\end{array}$ & $\begin{array}{l}-0.00138 \\
(0.127)\end{array}$ & $\begin{array}{l}-0.380 \\
(0.233)\end{array}$ & $\begin{array}{l}-0.00216 \\
(0.209)\end{array}$ \\
\hline \multirow[t]{2}{*}{$\begin{array}{l}\text { Foreign ownership } \\
(\mathrm{Y} / \mathrm{N})\end{array}$} & $0.321^{*}$ & 0.168 & $0.538^{*}$ & 0.272 \\
\hline & $(0.173)$ & $(0.163)$ & $(0.286)$ & $(0.269)$ \\
\hline \multirow{2}{*}{$\begin{array}{l}\text { Exports more than } \\
10 \% \text { of sales }(\mathrm{Y} / \mathrm{N})\end{array}$} & $-0.242^{* *}$ & $-0.225^{* *}$ & $-0.406^{*}$ & $-0.367^{* *}$ \\
\hline & $(0.123)$ & $(0.111)$ & $(0.208)$ & $(0.181)$ \\
\hline Size & $\begin{array}{l}-0.131^{* *} \\
(0.0659)\end{array}$ & $\begin{array}{l}-0.168^{* * *} \\
(0.0312)\end{array}$ & $\begin{array}{l}-0.233^{* *} \\
(0.117)\end{array}$ & $\begin{array}{l}-0.269^{* * * *} \\
(0.0506)\end{array}$ \\
\hline \multirow{2}{*}{$\begin{array}{l}\text { Firm part of larger } \\
\text { firm }(Y / N)\end{array}$} & 0.000651 & -0.0430 & -0.00785 & -0.0734 \\
\hline & $(0.121)$ & $(0.110)$ & $(0.206)$ & $(0.182)$ \\
\hline \multirow[t]{2}{*}{$\begin{array}{l}\text { Manager experience, } \\
\text { in years }\end{array}$} & $0.0106^{* * *}$ & $0.00836^{* *}$ & $0.0170^{* * *}$ & $0.0138^{* *}$ \\
\hline & $(0.00387)$ & $(0.00367)$ & $(0.00654)$ & $(0.00606)$ \\
\hline \multirow[t]{2}{*}{$\begin{array}{l}\text { Manager education } \\
\text { level }\end{array}$} & -0.0482 & -0.0219 & -0.0811 & -0.0352 \\
\hline & $(0.0604)$ & $(0.0538)$ & $(0.105)$ & $(0.0900)$ \\
\hline Observations & 5,111 & 5,111 & 5,111 & 5,111 \\
\hline Country FE & YES & $\mathrm{NO}$ & YES & $\mathrm{NO}$ \\
\hline
\end{tabular}

Note: Standard errors in parentheses. Estimation is done using survey weights. Constant and dummies not reported. $* * * 0<0.01, * * 0.05,{ }^{*} p<0.1$.

Results using the binary logit/probit model are similar to those using the ordered logit/probit model. Specifically, domestic-oriented and smaller firms are more likely to report political instability as a severer obstacle. These results hold whether we include country fixed effects or no. Models with country fixed effects (models 1 and 3 in Table 3) additionally show that the probability to choose political instability as a business obstacle increases with foreign ownership of the firm. This may be due to the fact that foreign-owned firms will find it more difficult to deal with or even fully understand the consequences of political instability and are therefore more inclined to respond to the survey question in such a way. Overall, results are mostly similar if we use the ordered or binary models, logit or the probit, and are robust to alternate specifications.

\subsection{Political Instability and Firm Performance}

Does political instability affect firm performance? This section answers this question by first using an OLS approach, and second a PSM approach. In what follows, firm performance is measured by the growth rate of sales and employment between 2009 and 2012. Our variable of interest is political instability, the binary 01 indicator used in the probity model reported in the previous section. 


\subsubsection{The OLS Evidence}

The OLS model specifies measures of firm performance as a function of political instability and a set of controls representing firm characteristics. In the first step, we run simple OLS regressions as in the following form:

$$
Y_{i s t}=f\left(X_{\text {ist }} \text { Politicalinstability }{ }_{\text {ist }}\right)
$$

where the dependent variable $Y_{\text {ist }}$ is a measure of firm performance (sales and employment growth) of firm $i$ in sector $s$ at time $t$. Independent variables include $X_{i s t}$ a set of control variables representing firm characteristics. Firms were asked: To what degree is political instability an obstacle to the current operations of this establishment? ${ }^{17}$ Our variable of interest Politicalinstability $y_{i s t}$ is a dummy variable that takes the value of one if the firm believes political instability to be a constraint (responses "major" and "very severe" obstacle), and zero (responses "no", "minor" and "moderate") otherwise. This is the same binary indicator we used in the previous section in the probit/logit model. Results are in reported in Table 4, with the dependent variable being either sales growth or employment growth, with and without country dummies.

Table 4: OLS.

\begin{tabular}{|c|c|c|c|c|}
\hline Variables & $\begin{array}{l}\text { Sales growth } \\
\text { (1) } \\
\text { OLS }\end{array}$ & $\begin{array}{l}(2) \\
\text { OLS }\end{array}$ & $\begin{array}{l}\text { Employment growth } \\
\text { (3) } \\
\text { OLS }\end{array}$ & $\begin{array}{l}\text { (4) } \\
\text { OLS }\end{array}$ \\
\hline Political instability & $\begin{array}{l}-0.121^{* * *} \\
(0.028)\end{array}$ & $\begin{array}{l}-0.062^{*} \\
(0.033)\end{array}$ & $\begin{array}{l}-0.062^{* * * *} \\
(0.017)\end{array}$ & $\begin{array}{l}-0.010 \\
(0.020)\end{array}$ \\
\hline Life of firm, in years & $\begin{array}{l}-0.003^{* * *} \\
(0.001)\end{array}$ & $\begin{array}{l}-0.003^{* * *} \\
(0.001)\end{array}$ & $\begin{array}{l}-0.002^{* * *} \\
(0.001)\end{array}$ & $\begin{array}{l}-0.002^{* * *} \\
(0.001)\end{array}$ \\
\hline Young firm $(\mathrm{Y} / \mathrm{N})$ & $\begin{array}{l}-0.038 \\
(0.085)\end{array}$ & $\begin{array}{l}-0.001 \\
(0.086)\end{array}$ & $\begin{array}{l}-0.004 \\
(0.051)\end{array}$ & $\begin{array}{l}0.026 \\
(0.050)\end{array}$ \\
\hline $\begin{array}{l}\text { Foreign ownership } \\
(\mathrm{Y} / \mathrm{N})\end{array}$ & $\begin{array}{l}-0.022 \\
(0.059)\end{array}$ & $\begin{array}{l}-0.042 \\
(0.063)\end{array}$ & $(0.051)$ & $(0.052)$ \\
\hline $\begin{array}{l}\text { Exports more than } \\
10 \% \text { of sales }(Y / N)\end{array}$ & $0.055^{*}$ & 0.051 & $0.068^{* *}$ & $0.067^{* *}$ \\
\hline & $(0.032)$ & $(0.032)$ & $(0.027)$ & $(0.027)$ \\
\hline Size & $\begin{array}{l}0.017 \\
(0.011)\end{array}$ & $\begin{array}{l}0.007 \\
(0.030)\end{array}$ & $\begin{array}{l}0.003 \\
(0.007)\end{array}$ & $\begin{array}{l}0.003 \\
(0.012)\end{array}$ \\
\hline $\begin{array}{l}\text { Firm part of larger } \\
\text { firm }(Y / N)\end{array}$ & 0.030 & 0.017 & -0.019 & -0.024 \\
\hline & $(0.044)$ & $(0.044)$ & $(0.021)$ & $(0.020)$ \\
\hline $\begin{array}{l}\text { Manager experience, } \\
\text { in years }\end{array}$ & $0.002^{*}$ & 0.002 & -0.000 & -0.001 \\
\hline & $(0.001)$ & $(0.001)$ & $(0.001)$ & $(0.001)$ \\
\hline Manager education & -0.026 & -0.021 & $-0.036^{* * *}$ & $-0.033^{* * *}$ \\
\hline & $(0.021)$ & $(0.021)$ & $(0.011)$ & $(0.012)$ \\
\hline Observations & 3,390 & 3,390 & 4,264 & 4,264 \\
\hline$R^{2}$ & 0.040 & 0.066 & 0.046 & 0.085 \\
\hline Country FE & No & Yes & No & Yes \\
\hline
\end{tabular}

Note: Robust standard errors in parentheses. Estimation is done using survey weights. Constant and country dummies not reported. $* * * 0.01, * * p<0.05, * p<0.1$.

Results suggest that political instability has had a negative and statistically significant effect on the performance of private firms in MENA. This is evident from the coefficient attached to the political instability dummy variable in all four equation reported in Table 4. Equations (1) and (2) have sales growth as the dependent variable, while eqs (3) and (4) have employment growth as the dependent variable. This result holds whether we include country fixed dummies (eqs (2) and (4)) or no (eqs (1) and (3)), and is robust to alternative specifications (where we replace the 10 percent exports dummy $(\mathrm{Y} / \mathrm{N})$ with the ordered exports variable, as well as foreign ownership dummy $(\mathrm{Y} / \mathrm{N})$ with the ordered foreign ownership variable).

Better firm performance is associated with export-oriented and younger firms. Other results from Table 4 suggest that better firm performance, in the form of sales growth and employment growth, is associated with firms that share certain characteristics; namely their export-orientation and years in operation. Additionally, in the employment growth models, firms with higher manager education are associated with higher employment 
growth. ${ }^{18}$ While in the sales growth model, firms with longer manager experience in the field witnessed higher sales growth.

\subsubsection{The Causal Evidence}

Correlation does not imply causation. In the sub-section above, we established that lower firm performance is indeed associated with higher perception of political instability as a business constraint. Although this result on average holds true, it does not say anything about the causal effect of political instability as a business constraint. The OLS and panel methodologies employed above simply reveal an association between political instability and firm performance, but we cannot formally give the coefficients a causal interpretation. This sub-section aims at doing just that using matching techniques adopted from the program evaluation literature.

To the best of our knowledge, there exists no study that tests the causal effect of political instability on individual firm performance, especially in the case of countries in the Middle East. A number of studies have tested the correlation between firm performance and different dimensions of the business environment, especially in developing countries. For example, Ayaggari, Demirguc-Kunt, and Maksimovic (2015) use simple OLS regressions to study the role of institutions in explaining firm performance using survey data from 120 developing countries from the World Bank ES database covering more than 44,000 formal firms, surveyed over the period 2006-2012. Xu (2011) uses firm-level research related to the World Bank Investment Climate Surveys to study the effect of firm initial conditions and complementary institutions on firm performance. In the case of countries in the MENA region, Kinda, Plane, and Véganzonès-Varoudakis (2015) use fixed effects regressions to study the correlation between the investment climate and firm technical efficiency in 22 MENA countries. They caution, however, that their results should be treated with caution, as they highlight covariates more than causal impacts. Desai and Olofsgard (2011) use data from the World Bank Enterprise Survey (WBES) from approximately 8000 firms in 40 developing countries. They find that politically connected firms benefit from easier access to credit, greater pricing power and lower administrative barriers, although this political influence restricts the firms' ability to fire workers. Earle and Gehlbach (2014) study the firm-level productivity consequences of political turnover using Ukraine's 2004 orange revolution.

There is a number of other studies in the literature that make use of enterprise survey data. For instance, Dethier, Hirn, and Straub (2010) provide a general survey of the recent literature examining the impact of the business climate on productivity and growth in developing countries using enterprise surveys. Using survey results from the WBES from 98 countries, including 10 from the MENA region, Bhattacharya and Wolde (2012) test the significance of business constraints on firms in the context of a standard growth model. They find that firm constraints help explain the growth underperformance in the MENA region. Bhattacharya and Wolde (2010) use data from the WBES to show that transport constraints and inefficiencies in customs clearance are associated with underperformance in trade in MENA. Ayyagari et al. (2016), using the WBES data, find that increased access to credit results in higher employment growth especially among micro, small and medium enterprises. Fakih and Ghazalian (2015) use WBES data to examine the implications of firm characteristics for the perceptions of firms on labor regulations and labor skill shortages.

Specifically, recognizing that perception of political instability can be endogenous to firm performance, we use a treatment effect estimator to interpret relationships as causal effects. As a result of this endogeneity problem, OLS estimates will suffer from a selection bias problem. We use an endogenous treatment-regression model that allows the estimation of a linear regression which includes an endogenous binary treatment variable. ${ }^{19}$ If an unobserved variable affects the treatment and the outcome, then we have an endogeneity problem. For instance, suppose we wish to know the effect of a job training program on employment. Further suppose that a third variable (for instance, motivation) affects both the treatment (participation in job program) and the outcome (employment). We have an endogeneity problem since we cannot observe motivation. Likewise, if our objective is to study the effect of political instability on firm performance, and if a third variable (for instance, political connections) affects both the treatment (perception of political stability) and the outcome (firm performance), then we have an endogeneity problem. This is why the endogenous treatment regression model comes in handy.

Treatment-effects estimators extract experimental-style causal effects from observational data. In simple terms, the idea is that we want to create an experimental environment using non-experimental data. To do this, each firm's probability to receive a binary treatment is estimated (with a probit or logit) as a function of observables (firms' characteristics). Firms with similar probabilities are matched. When firms have similar probabilities, their assignment to the treated group is largely random with respect to the relevant covariates, and thus mimics a controlled experiment, allowing us to accurately identify causal effects. In our context, the estimator allows comparison between treated (firms who perceive political instability as a business constraint) and control (firms who do not perceive political instability as a business constraint) units, and measures the 
average treatment effect on the outcome (firm performance), conditional on a set of observables (firm characteristics).

Estimation can be done through Maximum likelihood and/or a GMM estimator. Heckman $(1976,1978)$ developed the model. Maddala (1983) derives the maximum likelihood (MLE) and the control-function (CF) estimators of the model. More recently, Cameron and Trivedi (2005) and Wooldridge (2010) introduced the concept of the endogenous treatment-effects model and describe the control function estimator using the generalized method of moments (GMM).

Results can now be safely interpreted as causal effects. Tables (5) through (8) present the causal results using the different estimators outlined above for sales growth and employment growth, respectively. For all equations, ATE and ATT are estimated, with the associated F-statistic from the Wald test. In each of these tables, models (1) and (2) represent the MLE estimator, while models (3) and (4) represent the control function estimator using GMM. Furthermore, models (1) and (3) do not include country fixed effects, while models (2) and (4) include country dummies.

Results indicate that political instability has a negative causal effect on sales growth (Table 5). In all 4 models reported in Table (5), we find that the ATE and the ATT coefficients are negative and statistically significant. Focusing on the variable of interest, we can conclude that political instability has had a negative and causal effect on sales growth of private firms in MENA, all other variables held constant. ${ }^{20}$

Table 5: Endogenous treatment regression: sales growth, with restricted variance and correlation parameters across control and treatment groups.

\begin{tabular}{|c|c|c|c|c|}
\hline Variables & $\begin{array}{l}\text { Sales growth } \\
\text { (1) } \\
\text { MLE }\end{array}$ & $\begin{array}{l}\text { (2) } \\
\text { MLE }\end{array}$ & $\begin{array}{l}\text { (3) } \\
\text { CF }\end{array}$ & $\begin{array}{l}\text { (4) } \\
\mathrm{CF}\end{array}$ \\
\hline Political instability & $\begin{array}{l}-0.799 * * * \\
(0.055)\end{array}$ & $\begin{array}{l}-0.707^{* * *} \\
(0.072)\end{array}$ & $\begin{array}{l}-1.070^{* * * *} \\
(0.007)\end{array}$ & $\begin{array}{l}-0.995^{* * *} \\
(0.010)\end{array}$ \\
\hline Life of firm, in years & $\begin{array}{l}-0.004^{* * *} \\
(0.001)\end{array}$ & $\begin{array}{l}-0.005^{* * *} \\
(0.001)\end{array}$ & $\begin{array}{l}-0.005^{* * * *} \\
(0.001)\end{array}$ & $\begin{array}{l}-0.005^{* * * *} \\
(0.001)\end{array}$ \\
\hline Young firm $(\mathrm{Y} / \mathrm{N})$ & $\begin{array}{l}-0.245^{* *} \\
(0.106)\end{array}$ & $\begin{array}{l}-0.200^{*} \\
(0.103)\end{array}$ & $\begin{array}{l}-0.324^{* * * *} \\
(0.092)\end{array}$ & $\begin{array}{l}-0.281^{* * *} \\
(0.084)\end{array}$ \\
\hline \multirow{2}{*}{$\begin{array}{l}\text { Foreign ownership } \\
(\mathrm{Y} / \mathrm{N})\end{array}$} & -0.008 & -0.026 & -0.002 & -0.023 \\
\hline & $(0.079)$ & $(0.080)$ & $(0.068)$ & $(0.069)$ \\
\hline \multirow{2}{*}{$\begin{array}{l}\text { Exports more than } \\
10 \% \text { of sales }(\mathrm{Y} / \mathrm{N})\end{array}$} & 0.015 & 0.012 & -0.001 & -0.005 \\
\hline & $(0.045)$ & $(0.044)$ & $(0.046)$ & $(0.046)$ \\
\hline Size & $\begin{array}{l}-0.027^{* *} \\
(0.013)\end{array}$ & $\begin{array}{l}-0.040 \\
(0.026)\end{array}$ & $\begin{array}{l}-0.044^{* * *} \\
(0.012)\end{array}$ & $\begin{array}{l}-0.052^{* * *} \\
(0.014)\end{array}$ \\
\hline \multirow[t]{2}{*}{$\begin{array}{l}\text { Firm part of larger } \\
\text { firm }(\mathrm{Y} / \mathrm{N})\end{array}$} & $0.100^{* *}$ & $0.084^{*}$ & $0.134^{* * *}$ & $0.119^{* * *}$ \\
\hline & $(0.045)$ & $(0.044)$ & $(0.024)$ & $(0.025)$ \\
\hline \multirow[t]{2}{*}{$\begin{array}{l}\text { Manager experience, } \\
\text { in years }\end{array}$} & $0.007^{* * * *}$ & $0.006^{* * * *}$ & $0.008^{* * *}$ & $0.008^{* * * *}$ \\
\hline & $(0.002)$ & $(0.002)$ & $(0.001)$ & $(0.001)$ \\
\hline \multirow{2}{*}{$\begin{array}{l}\text { Manager education } \\
\text { level }\end{array}$} & $-0.047^{* *}$ & $-0.044^{* *}$ & $-0.054^{* * *}$ & $-0.049^{* *}$ \\
\hline & $(0.023)$ & $(0.022)$ & $(0.019)$ & $(0.021)$ \\
\hline Observations & 3,390 & 3,390 & 3,390 & 3,390 \\
\hline Rho & 0.844 & 0.817 & 1 & . \\
\hline $\begin{array}{l}\text { LR test for } \\
\text { independent } \\
\text { equations }\end{array}$ & $50.79^{* * *}$ & $273.26^{* * *}$ & & \\
\hline Log likelihood & -3631.3462 & -3514.299 & & \\
\hline AIC & 7312.692 & 7082.597 & & \\
\hline BIC & 7436.282 & 7249.443 & & \\
\hline ATE & $\begin{array}{l}-0.799 \\
(211.24)^{* * * *}\end{array}$ & $\begin{array}{l}-0.707 \\
(96.75)^{* * * *}\end{array}$ & $\begin{array}{l}-1.070 \\
(26224.34)^{* * *}\end{array}$ & $\begin{array}{l}-0.995 \\
(9211.79)^{* * *}\end{array}$ \\
\hline ATT & $\begin{array}{l}-0.799 \\
(211.24)^{* * *}\end{array}$ & $\begin{array}{l}-0.707 \\
(96.75)^{* * * *}\end{array}$ & $\begin{array}{l}-1.069 \\
(26224.34)^{* * * *}\end{array}$ & $\begin{array}{l}-0.996 \\
(9211.79)^{* * * *}\end{array}$ \\
\hline Country FE & $\mathrm{NO}$ & YES & NO & YES \\
\hline
\end{tabular}


Note: Estimation is done using survey weights. Constant and country dummies not reported.

ATE is Average Treatment Effect, while ATT is Average Treatment Effect on the Treated. F statistics from the Wald test are shown under both. Survey weights are not used to estimate the LR test for independent equations, Akaike's Information Criteria (AIC) and Bayesian Information Criteria (BIC).

$* * * 0<0.01, * * 0<0.05, * p<0.1$.

MLE: Estimator using Maximum Likelihood Estimation, with linearized standard errors in parentheses.

CF: Control function estimator using GMM, with linearized standard errors in parentheses.

Endogeneity has effects on the estimation. In the MLE, ${ }^{21}$ the likelihood-ratio test (LR test for independent equations) indicates that we can reject the null hypothesis of no correlation between the treatment-assignment and outcome errors. In model (1) for example, the estimated correlation between the treatment-assignment errors and the outcome errors, $\rho$, is 0.844 . The positive relationship indicates that unobservables that raise the outcome (observed firm performance) tend to occur with unobservables that raise the treatment (perception of effect of political instability on firm operations).

Correcting for this endogeneity problem changes some of the earlier OLS results on the relationship between firm characteristics and firm sales growth. Comparing results from Table 4 with Table 5, we notice that export-orientation is no longer statistically related to firm sales growth. Results also indicate that sales growth of both older and younger firms have been affected by political instability. Sales growth of larger sized firms seem to be more hit than smaller firms, although firms that are part of a larger establishment have seen positive correlation with sales growth, all else equal. Manager experience and manager education levels are both positively correlated with sales growth. These results hold for both models (1) and (2) although model (2) is our preferred model as it has a lower-LogLikelihood, AIC and BIC.

Results are robust to different estimations (Table 6). In the above models, outcome error variance and correlation parameters were restricted (the same) across control and treatment groups. As a robustness check in Table (6), we allow the outcome error variance and correlation parameters to vary across the control (firms where political stability is not an obstacle) and treatment (firms where political instability is an obstacle) group, and results are unchanged. In models (1) through (4), the estimate of the correlation of the treatment-assignment errors for the control group $(\rho 0)$ is positive, indicating that unobservables that increase the outcome (sales growth) tend to occur with unobservables that increase the treatment (perception of effects of political instability on firm operations). Because $\rho 1$ is also positive, we make the same interpretation for firms in the treatment group. Furthermore, for all models, ${ }^{22}$ the estimate $\rho 1$ is larger than $\rho 0$, indicating a stronger relationship between the unobservables (such as political connections) and treatment outcomes in the treated group. Overall, results in Table 6 are very similar to those of Table 5.

Table 6: Endogenous treatment regression: sales growth, with different variance and correlation parameters across control and treatment groups.

\begin{tabular}{|c|c|c|c|c|}
\hline Variables & $\begin{array}{l}\text { Sales growth } \\
\text { (1) } \\
\text { MLE }\end{array}$ & $\begin{array}{l}(2) \\
\text { MLE }\end{array}$ & $\begin{array}{l}(3) \\
\mathrm{CF}\end{array}$ & $\begin{array}{l}(4) \\
\mathrm{CF}\end{array}$ \\
\hline Political instability & $\begin{array}{l}-0.805^{* * *} \\
(0.068)\end{array}$ & $\begin{array}{l}-0.756^{* * *} \\
(0.072)\end{array}$ & $\begin{array}{l}-0.997^{* * * *} \\
(0.324)\end{array}$ & $\begin{array}{l}-1.704 \\
(356.665)\end{array}$ \\
\hline Life of firm, in years & $\begin{array}{l}-0.004^{* * *} \\
(0.001)\end{array}$ & $\begin{array}{l}-0.005^{* * *} \\
(0.001)\end{array}$ & $\begin{array}{l}-0.005^{* * *} \\
(0.001)\end{array}$ & $\begin{array}{l}-0.006 \\
(0.811)\end{array}$ \\
\hline Young firm $(\mathrm{Y} / \mathrm{N})$ & $\begin{array}{l}-0.244^{* *} \\
(0.100)\end{array}$ & $\begin{array}{l}-0.219^{* *} \\
(0.096)\end{array}$ & $\begin{array}{l}-0.303^{*} \\
(0.155)\end{array}$ & $\begin{array}{l}-0.550 \\
(120.167)\end{array}$ \\
\hline \multirow[t]{2}{*}{$\begin{array}{l}\text { Foreign ownership } \\
(\mathrm{Y} / \mathrm{N})\end{array}$} & -0.003 & -0.018 & -0.013 & 0.033 \\
\hline & $(0.080)$ & $(0.083)$ & $(0.059)$ & $(2.895)$ \\
\hline \multirow[t]{2}{*}{$\begin{array}{l}\text { Exports more than } \\
10 \% \text { of sales }(\mathrm{Y} / \mathrm{N})\end{array}$} & 0.013 & 0.011 & 0.010 & -0.047 \\
\hline & $(0.045)$ & $(0.046)$ & $(0.051)$ & $(24.028)$ \\
\hline Size & $\begin{array}{l}-0.029^{*} \\
(0.015)\end{array}$ & $\begin{array}{l}-0.041 \\
(0.029)\end{array}$ & $\begin{array}{l}-0.032 \\
(0.034)\end{array}$ & $\begin{array}{l}-0.106 \\
(18.638)\end{array}$ \\
\hline \multirow[t]{2}{*}{$\begin{array}{l}\text { Firm part of larger } \\
\text { firm }(Y / N)\end{array}$} & $0.117^{* * * *}$ & $0.106^{* *}$ & 0.111 & 0.197 \\
\hline & $(0.044)$ & $(0.044)$ & $(0.076)$ & $(38.308)$ \\
\hline \multirow{2}{*}{$\begin{array}{l}\text { Manager experience, } \\
\text { in years }\end{array}$} & $0.007^{* * * *}$ & $0.007^{* * *}$ & $0.007^{*}$ & 0.009 \\
\hline & $(0.002)$ & $(0.002)$ & $(0.004)$ & (2.188) \\
\hline \multirow[t]{2}{*}{$\begin{array}{l}\text { Manager education } \\
\text { level }\end{array}$} & $-0.047^{* *}$ & $-0.046^{*}$ & $-0.049^{* *}$ & -0.072 \\
\hline & $(0.023)$ & $(0.024)$ & $(0.023)$ & $(10.812)$ \\
\hline Observations & 3,390 & 3,390 & 3,390 & 3,390 \\
\hline
\end{tabular}




\begin{tabular}{lllll} 
Rho0 $(\rho 0)$ & 0.799 & 0.813 & 1 & 0.436 \\
Rho1 $(\rho 1)$ & 0.915 & 0.894 & 0.779 & 0.714 \\
LR test for & $71.07^{* * *}$ & $278.78^{* * *}$ & & \\
independent & & & & \\
equations & & -3509.281 & \\
Log likelihood & -3626.203 & 7076.562 & & -1.704 \\
AIC & 7296.405 & 7255.766 & -0.997 & $(0.00)$ \\
BIC & 7432.354 & -0.756 & $(9.46)^{* * *}$ & -1.704 \\
ATE & -0.805 & $(109.09)^{* * *}$ & -0.997 & $(0.00)$ \\
ATT & $(138.90)^{* * *}$ & -0.756 & $(9.46)^{* * *}$ & YES \\
& -0.805 & $(109.09)^{* * *}$ & NO & \\
\hline
\end{tabular}

Note: Estimation is done using survey weights. Constant and country dummies not reported.

ATE is Average Treatment Effect, while ATT is Average Treatment Effect on the Treated. F statistics from the Wald test are shown under both. Survey weights are not used to estimate the LR test for independent equations, Akaike's Information Criteria (AIC) and Bayesian Information Criteria (BIC).

$* * * 0<0 . * * * 0.05, * p<0.1$.

MLE: Estimator using Maximum Likelihood Estimation, with linearized standard errors in parentheses.

CF: Control function estimator using GMM, with linearized standard errors in parentheses.

Concerning the employment growth equation, political instability has a negative and statistically significant causal effect (Table 7). Empirical results are mixed. Model (1) suggests a positive ATE/ATT, but we can discard that model as it does not include country dummies. Model (2) includes country dummies and uses the MLE method. Results using the endogenous treatment regression model indicate that ATE/ATT are negative and significant, implying we can interpret this coefficient as a causal effect, after correcting for potential endogeneity problems in our specification. Furthermore, model (2) is our preferred model as it has a lower-LogLikelihood, AIC and BIC. Models (3) and (4) using the control function estimator using GMM point to an ATE/ATT that is statistically insignificant from zero.

Table 7: Endogenous treatment regression: employment growth, with restricted variance and correlation parameters across control and treatment groups.

\begin{tabular}{|c|c|c|c|c|}
\hline Variables & $\begin{array}{l}\text { Employment growth } \\
\text { (1) } \\
\text { MLE }\end{array}$ & $\begin{array}{l}(2) \\
\text { MLE }\end{array}$ & $\begin{array}{l}\text { (3) } \\
\text { CF }\end{array}$ & $\begin{array}{l}\text { (4) } \\
\mathrm{CF}\end{array}$ \\
\hline Political instability & $\begin{array}{l}0.176^{* * *} \\
(0.068)\end{array}$ & $\begin{array}{l}-0.379^{* * *} \\
(0.049)\end{array}$ & $\begin{array}{l}0.037 \\
(6.908)\end{array}$ & $\begin{array}{l}-0.604 \\
(24.226)\end{array}$ \\
\hline Life of firm, in years & $\begin{array}{l}-0.002^{* * *} \\
(0.001)\end{array}$ & $\begin{array}{l}-0.002^{* * *} \\
(0.001)\end{array}$ & $\begin{array}{l}-0.002 \\
(0.002)\end{array}$ & $\begin{array}{l}-0.003 \\
(0.005)\end{array}$ \\
\hline Young firm $(\mathrm{Y} / \mathrm{N})$ & $\begin{array}{l}0.026 \\
(0.052)\end{array}$ & $\begin{array}{l}-0.021 \\
(0.066)\end{array}$ & $\begin{array}{l}0.009 \\
(0.880)\end{array}$ & $\begin{array}{l}-0.048 \\
(2.997)\end{array}$ \\
\hline $\begin{array}{l}\text { Foreign ownership } \\
(\mathrm{Y} / \mathrm{N})\end{array}$ & $(0.051)$ & $(0.061)$ & $(0.108)$ & $(0.314)$ \\
\hline \multirow[t]{2}{*}{$\begin{array}{l}\text { Exports more than } \\
10 \% \text { of sales }(\mathrm{Y} / \mathrm{N})\end{array}$} & $0.095^{* * *}$ & 0.027 & 0.079 & 0.001 \\
\hline & $(0.027)$ & $(0.034)$ & $(0.765)$ & $(2.627)$ \\
\hline Size & $\begin{array}{l}0.016^{*} \\
(0.009)\end{array}$ & $\begin{array}{l}-0.018 \\
(0.014)\end{array}$ & $\begin{array}{l}0.009 \\
(0.379)\end{array}$ & $\begin{array}{l}-0.030 \\
(1.360)\end{array}$ \\
\hline \multirow{2}{*}{$\begin{array}{l}\text { Firm part of larger } \\
\text { firm }(Y / N)\end{array}$} & $-0.036^{*}$ & 0.004 & -0.026 & 0.021 \\
\hline & $(0.022)$ & $(0.021)$ & $(0.512)$ & (1.733) \\
\hline \multirow[t]{2}{*}{$\begin{array}{l}\text { Manager experience, } \\
\text { in years }\end{array}$} & -0.001 & 0.001 & -0.001 & 0.002 \\
\hline & $(0.001)$ & $(0.001)$ & $(0.033)$ & $(0.112)$ \\
\hline \multirow{2}{*}{$\begin{array}{l}\text { Manager education } \\
\text { level }\end{array}$} & $-0.036^{* * *}$ & $-0.031^{* *}$ & $-0.036^{* * *}$ & -0.031 \\
\hline & $(0.013)$ & $(0.013)$ & $(0.006)$ & $(0.084)$ \\
\hline Observations & 4,264 & 4,264 & 4,264 & 4,264 \\
\hline Rho & -0.487 & 0.701 & -0.217 & 0.935 \\
\hline $\begin{array}{l}\text { LR test for } \\
\text { independent } \\
\text { equations }\end{array}$ & 1.15 & $47.35^{* * *}$ & 0.05 & 0.73 \\
\hline Log likelihood & -3597.092 & -3475.026 & & \\
\hline
\end{tabular}




\begin{tabular}{|c|c|c|c|c|}
\hline AIC & 7234.183 & 7004.051 & & \\
\hline BIC & 7362.588 & 7177.398 & & \\
\hline \multirow[t]{2}{*}{ ATE } & 0.176 & -0.379 & 0.037 & -0.604 \\
\hline & $(6.67)^{* * *}$ & $(59.85)^{* * *}$ & $(0.00)$ & $(0.00)$ \\
\hline \multirow[t]{2}{*}{ ATT } & 0.176 & -0.379 & 0.037 & -0.604 \\
\hline & $(6.67)^{* * *}$ & $(59.85)^{* * *}$ & $(0.00)$ & $(0.00)$ \\
\hline Country FE & NO & YES & NO & YES \\
\hline
\end{tabular}

Note: Estimation is done using survey weights. Constant and country dummies not reported.

ATE is Average Treatment Effect, while ATT is Average Treatment Effect on the Treated. F statistics from the Wald test are shown under both. Survey weights are not used to estimate the LR test for independent equations, Akaike's Information Criteria (AIC) and Bayesian Information Criteria (BIC).

$* * * p<0.01, * * p<0.05, * p<0.1$

MLE: Estimator using Maximum Likelihood Estimation, with linearized standard errors in parentheses.

CF: Control function estimator using GMM, with linearized standard errors in parentheses.

Correcting for the endogeneity problem does not largely change our earlier OLS results on the relationship between firm characteristics and firm employment growth. Comparing results from Table 4 with Table 7, we can see that firm characteristics such as export-orientation, manager education level and firm life in years have retained their statistical significance and coefficient sign.

Results are robust to different estimation procedures (Table 8). Allowing the variance and correlation parameters to vary across control and treatment groups reconfirm overall results. Comparing Table 7 and Table 8 show that the ATE/ATT remains negative and statistically significant in all models, with the exception of model (4) which we can discard as GMM convergence was not achieved. The coefficient attached to our variable of interest, political instability, is negative and statistically significant in models (1) through (3). Results also indicate that firm characteristics such as manager education level, export-orientation and firm life in years remain statistically significant with the expected coefficient signs. In models (1) through (4), the estimate of the correlation of the treatment-assignment errors for the control group $(\rho 0)$ is positive, indicating that unobservables that increase the outcome (employment growth) tend to occur with unobservables that increase the treatment (perception of effects of political instability on firm operations). Because $\rho 1$ is also positive, we make the same interpretation for firms in the treatment group. Furthermore, for all models, ${ }^{23}$ the estimate $\rho 1$ is larger than $\rho 0$, indicating, as one would expect, a stronger relationship between the unobservables (such as political connections) and treatment outcomes in the treated group.

Table 8: Endogenous treatment regression: employment growth, with different variance and correlation parameters across control and treatment groups.

\begin{tabular}{|c|c|c|c|c|}
\hline Variables & $\begin{array}{l}\text { Employment growth } \\
\text { (1) } \\
\text { MLE }\end{array}$ & $\begin{array}{l}(2) \\
\text { MLE }\end{array}$ & $\begin{array}{l}\text { (3) } \\
\mathrm{CF}\end{array}$ & $\begin{array}{l}\text { (4) } \\
\mathrm{CF}\end{array}$ \\
\hline Political instability & $\begin{array}{l}-0.336^{* *} \\
(0.149)\end{array}$ & $\begin{array}{l}-0.314^{* * * *} \\
(0.084)\end{array}$ & $\begin{array}{l}-0.798^{* * *} \\
(0.010)\end{array}$ & $\begin{array}{l}-1.522 \\
(1978.159)\end{array}$ \\
\hline Life of firm, in years & $\begin{array}{l}-0.002^{* * *} \\
(0.001)\end{array}$ & $\begin{array}{l}-0.003^{* * *} \\
(0.001)\end{array}$ & $\begin{array}{l}-0.002^{* * * *} \\
(0.001)\end{array}$ & $\begin{array}{l}-0.003 \\
(0.527)\end{array}$ \\
\hline Young firm $(\mathrm{Y} / \mathrm{N})$ & $\begin{array}{l}-0.047 \\
(0.063)\end{array}$ & $\begin{array}{l}-0.019 \\
(0.061)\end{array}$ & $\begin{array}{l}-0.097 \\
(0.087)\end{array}$ & $\begin{array}{l}-0.154 \\
(258.937)\end{array}$ \\
\hline $\begin{array}{l}\text { Foreign ownership } \\
(\mathrm{Y} / \mathrm{N})\end{array}$ & 0.041 & 0.025 & 0.046 & 0.105 \\
\hline & $(0.053)$ & $(0.056)$ & $(0.050)$ & $(35.062)$ \\
\hline \multirow{2}{*}{$\begin{array}{l}\text { Exports more than } \\
10 \% \text { of sales }(Y / N)\end{array}$} & 0.035 & 0.031 & -0.011 & -0.122 \\
\hline & $(0.035)$ & $(0.033)$ & $(0.037)$ & $(239.711)$ \\
\hline Size & $\begin{array}{l}-0.013 \\
(0.011)\end{array}$ & $\begin{array}{l}-0.014 \\
(0.014)\end{array}$ & $\begin{array}{l}-0.037^{* * * *} \\
(0.009)\end{array}$ & $\begin{array}{l}-0.092 \\
(103.827)\end{array}$ \\
\hline \multirow[t]{2}{*}{$\begin{array}{l}\text { Firm part of larger } \\
\text { firm }(\mathrm{Y} / \mathrm{N})\end{array}$} & 0.002 & -0.001 & 0.023 & 0.129 \\
\hline & $(0.022)$ & $(0.021)$ & $(0.018)$ & (159.482) \\
\hline \multirow[t]{2}{*}{$\begin{array}{l}\text { Manager experience, } \\
\text { in years }\end{array}$} & 0.002 & 0.001 & $0.003^{* * *}$ & 0.004 \\
\hline & $(0.001)$ & $(0.001)$ & $(0.001)$ & $(9.452)$ \\
\hline \multirow{2}{*}{$\begin{array}{l}\text { Manager education } \\
\text { level }\end{array}$} & $-0.033^{* * *}$ & $-0.030^{* *}$ & $-0.034^{* *}$ & 0.001 \\
\hline & $(0.012)$ & $(0.013)$ & $(0.014)$ & (7.514) \\
\hline Observations & 4,264 & 4,264 & 4,264 & 4,264 \\
\hline Rho0 $(\rho 0)$ & 0.451 & 0.566 & 1 & 0.537 \\
\hline
\end{tabular}




\begin{tabular}{|c|c|c|c|c|}
\hline Rho1 (م1) & 0.737 & 0.701 & . & 0.992 \\
\hline $\begin{array}{l}\text { LR test for } \\
\text { independent } \\
\text { equations }\end{array}$ & $14.93^{* * *}$ & $31.99 * * *$ & & \\
\hline Log likelihood & -3590.203 & -3474.506 & & \\
\hline $\mathrm{AIC}$ & 7224.405 & 7007.012 & & \\
\hline BIC & 7365.65 & 7193.199 & & \\
\hline ATE & $\begin{array}{l}-0.336 \\
(5.09)^{* *}\end{array}$ & $\begin{array}{l}-0.314 \\
(13.98)^{* * *}\end{array}$ & $\begin{array}{l}-0.798 \\
(656.26)^{* * * *}\end{array}$ & $\begin{array}{l}-1.522 \\
(0.00)\end{array}$ \\
\hline ATT & $\begin{array}{l}-0.336 \\
(5.09)^{* *}\end{array}$ & $\begin{array}{l}-0.314 \\
(13.98)^{* * *}\end{array}$ & $\begin{array}{l}-0.798 \\
(656.26)^{* * * *}\end{array}$ & $\begin{array}{l}-1.522 \\
(0.00)\end{array}$ \\
\hline Country FE & $\mathrm{NO}$ & YES & NO & YES \\
\hline
\end{tabular}

Overall, results suggest that political instability has had a negative and statistically significant effect on sales and employment growth of private firms in MENA. Using OLS regressions, we find a negative and statistically significant association between our variable of interest, political instability, and firm performance. Correcting for endogeneity problems, we use an endogenous treatment regression model, and find that political instability has had a negative and causal effect on firm performance.

\section{Conclusion}

This paper aimed at understanding the relationship between firm characteristics and their perception of the effect of political instability on their operations as well as the important negative effects of political instability on firm performance. Specifically, using firm-level data from an EBRD/EIB/WB joint survey covering more than 6,000 private firms in eight countries in MENA, this paper (i) examines the relationship between different firm characteristics and their perception of the effect of political instability on their operations and (ii) tests whether political instability has had a negative effect on firm performance; namely the firms' sales and employment growth.

On firm characteristics, we find that domestic-oriented and smaller-sized firms are more likely to report political instability as a severer obstacle. Results indicated that these firms are more likely to report political instability as a severer obstacle, as compared to export-oriented and larger-sized firms. This result holds under different econometric estimation techniques (ordered probit/logit vs binary probit/logit), as well as other robustness checks such as changing specifications and inclusion of country fixed dummies.

On firm performance, results suggest that political instability has had a negative and statistically significant effect on sales and employment growth of private firms in MENA. Using OLS regressions, we find that the coefficient attached to political instability indicator variable is negative and statistically significant, suggesting that such perception has been associated with lower firm performance. Furthermore, we find that better firm performance is associated with export-oriented and younger firms. Results hold against alternative specifications and whether we include country fixed dummies or no.

Correcting for endogeneity problems, we still find that political instability has had a negative and causal effect on firm performance. Recognizing that correlation does not imply causation and that other unobservable variables may create endogeneity problems, rendering the OLS estimates biased and inefficient, we use an endogenous treatment-regression model that allows the estimation of a linear regression which includes an endogenous binary treatment variable. Results indicate that firms' perception of the effects of political instability on their operations, holding all else constant, has had a negative causal effect on their performance; both sales and employment growth.

\section{Acknowledgment}

The views expressed in this paper are those of the author and should not be attributed to the IMF, its Executive Board, or its management. The author would like to thank Hind ELFalaky for research assistance. 


\section{Notes}

${ }^{1}$ All material - including the full questionnaire, sampling, data, and variable description - is accessible at http://ebrdbeeps.com/data/mena-es-2013-2015/

${ }^{2}$ Not included in the survey are agriculture, fishing and extractive industries, as well as utilities and some services sectors, such as financial services, education and healthcare.

${ }^{3}$ This is question M.1. in the survey questionnaire.

${ }^{4}$ This is question J.30e in the survey questionnaire.

${ }^{5}$ This is question D.3. in the survey questionnaire.

${ }^{6}$ This is question B.2. in the survey questionnaire.

${ }^{7}$ This is question B.5. in the survey questionnaire.

${ }^{8}$ This is question A.6 in the survey questionnaire. Firm size is defined as small (5-19 employees), medium (20-99 employees), and large (more than 100 employees)

${ }^{9}$ This is question D.2. in the survey questionnaire.

${ }^{10}$ This is question N.3. in the survey questionnaire.

${ }^{11}$ This is question L.1. in the survey questionnaire.

${ }^{12}$ This is question L.2. in the survey questionnaire.

${ }^{13}$ An ordinal variable is a variable that is categorical and ordered.

${ }^{14}$ It is important to note in this context what Hausmann and Rodrik described as the Camel-Hippo problem. Camels interviewed in the desert would not identify water as a constraint because they have endogenized the problem. Similarly, large firms may not report political instability as business constraint, compared to small firms, but we may not know whether this is because political instability is not a constraint or whether these have been endogenized. Such problems of endogeneity are described in more detail in the next section.

${ }^{15}$ As robustness checks, we replace the 10 percent exports dummy $(\mathrm{Y} / \mathrm{N})$ with the ordered exports variable, as well as foreign ownership dummy $(\mathrm{Y} / \mathrm{N})$ with the ordered foreign ownership variable. Results are largely unchanged.

${ }^{16}$ Kuntchev et al. (2014) perform a similar analysis to study the relationship between access to finance in SMEs and firm characteristics in more than 100 countries.

${ }^{17}$ This is question J.30e in the survey questionnaire.

${ }^{18}$ The manager education level is in response to the question: What is the highest level of education completed by the Top Manager? This is question MNAB.7b. in the survey questionnaire. Responses range from "university degree or higher" with value 1 to "incomplete primary school" with value 5. Thus, higher values of this indicator indicate lower level of education.

${ }^{19}$ This model is also sometimes referred to as the endogenous binary-variable model or the endogenous dummy-variable model.

${ }^{20}$ The estimated ATE and ATT do not differ since the variances of the outcome errors and their correlations with the treatment-assignment errors do not differ across the control and treatment groups.

${ }^{21}$ In the CF models (3) and (4), convergence in GMM is not achieved, and thus these statistics are not reported.

${ }^{22}$ With the exception of model (3) in Table 6 , where $\rho 1$ is smaller than $\rho 0$, indicating a stronger relationship between the unobservables and treatment outcomes in the control group.

${ }^{23}$ with the exception of model (3) in Table 8, where GMM convergence is not achieved.

\section{References}

Ayaggari, M., A. Demirguc-Kunt, and V. Maksimovic. (2015).World Bank Policy Research Working Paper No. 7406 Washington, DC: The World Bank Group Are Larger Firms Born or Made: Evidence from Developing Countries .

Ayyagari, M., P. Juarros, M. S. Martinez Peria, and S. Singh. (2016). World Bank Policy Research Working Paper No. 7604 Washington, DC: The World Bank Group Access to Finance and Job Growth: Firm-Level Evidence across Developing Countries .

Bhattacharya, R., and H. Wolde. 2012. "Business Environment Constraints on Growth in the MENA Region ." Middle East Development Journal 4 (01): 1-18.

Bhattacharya, R., and H. Wolde. (2010).IMFWP10/31 Washington, DC: International Monetary Fund Constraints on Trade in the MENA Region.

Cameron, A. C., and P. K. Trivedi. 2005. Microeconometrics: Methods and Applications. New York: Cambridge University Press

Desai, R., and A. Olofsgard. 2011. "The Costs of Political Influence: Firm-Level Evidence from Developing Countries ." Quarterly Journal of Political Science 6: 137-178.

Dethier, J.-J., M. Hirn, and S. Straub. 2010. “Explaining Enterprise Performance in Developing Countries with Business Climate Survey Data ." The World Bank Research Observer 26: 258-309.

Earle, J. S., and S. Cehlbach. (2014).IZA Discussion Paper No. 8510 The Productivity Consequences of Political Turnover: Firm-Level Evidence from Ukraine's Orange Revolution.

EBRD/EIB/WB. 2015. “A joint report by The European Bank for Reconstruction and Development (EBRD), the European Investment Bank (EIB), and the World Bank Croup (WBC)." In The MENA enterprise surveys (MENA ES): A report on methodology and observations.

EBRD/EIB/WB. 2016. "A joint report by The European Bank for Reconstruction and Development (EBRD), the European Investment Bank (EIB), and the World Bank Croup (WBC)." In What's holding back the private sector in MENA? Lessons from the enterprise survey.

Fakih, A., and P. L. Chazalian. 2015. "What Factors Influence Firm Perceptions of Labour Market Constraints to Growth in the MENA Region? ." International Journal of Manpower 36 (8): 1181-1206.

Heckman, J. 1976. "The Common Structure of Statistical Models of Truncation, Sample Selection and Limited Dependent Variables and a Simple Estimator for Such Models." Annals of Economic and Social Measurement 5: 475-492.

Heckman, J. 1978. “Dummy Endogenous Variables in a Simultaneous Equation System .” Econometrica 46: 931-959. 
Kinda, T., P. Plane, and M.-A. Véganzonès-Varoudakis. 2015. “Does Investment Climate Matter for Firms' Technical Efficiency: An Application to Middle Eastern and North African Manufacturing ." Journal of International Development 27 (7): 1267-1293.

Kuntchev, V., R. Ramalho, J. Rodriguez-Meza, and J. Yang. (2014).Working Paper by the Enterprise Analysis Unit What Have We Learned from the Enterprise Surveys regarding Access to Credit by Smes? .

Maddala, G. S. 1983. Limited-Dependent and Qualitative Variables in Econometrics. Cambridge: Cambridge University Press.

Wooldridge, J. M. 2010. Econometric Analysis of Cross Section and Panel Data., 2nd. Cambridge, MA: MIT Press.

Xu, L. C. 2011. "The Effect of Business Environment on Development: Surveying New Firm Level Evidence." The World Bank Research Observer 26 (2): 310-340. 